\title{
Stromboli - the best place to actively learn and understand the behavior of an active volcano and its processes
}

\author{
Stromboli - najlepsze miejsce do poznania aktywnego wulkanu \\ i zrozumienia procesów wulkanicznych
}

\author{
Krzysztof Bąk ${ }^{1}$, Marta Bąk ${ }^{2}$, Mariusz Szubert ${ }^{1}$ \\ ${ }^{1}$ Pedagogical University of Cracow, Geography and Biology Faculty, Institute of Geography, \\ ul. Podchorążych 2, 30-084 Kraków; \\ e-mail:kbak@cyf-kr.edu.pl;sgszuber@up.krakow.pl \\ ${ }^{2}$ AGH University of Science and Technology, Faculty of Geology, Geophysics and Environmental Protection, \\ al. Mickiewicza 30, 30-059 Kraków; \\ e-mail:martabak@agh.edu.pl
}
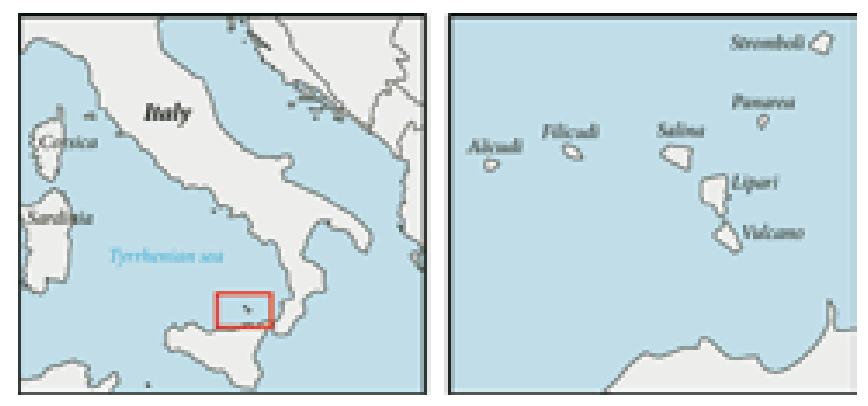

Abstract: Basaltic volcanism, a dominant mode of volcanic activity on Earth, occurs as explosive eruptions, resulting from the exsolution of magmatic gases and is exhibited by Strombolian and Hawaiian types. Strombolian activity takes its name from frequent, small-scale explosions of the Stromboli Volcano, which was formed within the Aeolian Islands, north of Sicily. This paper presents the volcanic structure and features of its activity, based on the results of numerous studies carried out during the last 15 years. In the intention of the authors, this educational presentation would be an incentive to make a decision to travel to Stromboli and see its present-day activity and its effects from just a few hundred meters. To have a safe experience and to avoid accidents and injuries, the tourists need to have sufficient up-to-date information, before they embark on their adventure.

Key words: the Aeolian Islands, basaltic volcanism, Strombolian activity, causes of eruptions, rocks and relief of volcano, accessible tourism

Treść: Wulkanizm bazaltowy (dominujacy typ aktywności wulkanicznej na Ziemi), który jest związany z ekshalacja gazów pomagmowych, ma charakter eksplozywnych erupcji określanych mianem typu hawajskiego i strombolijskiego. Aktywność strombolijska charakteryzuja częste, niewielkiej objętości wybuchy, które wystęuja m.in. na czynnym wulkanie Stromboli, znajdujacym się w tuku Wysp Liparyjskich (Eolskich), na pótnoc od Sycylii. W artykule przedstawiono budowe wulkanu, jego działalność i przyczyny tej działalności na podstawie wyników licznych badań, przeprowadzonych $w$ ciagu ostatnich 15 lat. W intencji autorów przedstawione $w$ sposób możliwie prosty informacje, zdjęcia i ryciny tego wulkanu maja być materiałem edukacyjnym i jednocześnie zachęta do podjęcia decyzji o podróży, żeby z odległości kilkuset metrów móc samemu zobaczyć erupcje wulkaniczne. Aby poznawanie wulkanu było bezpieczne, turyści powinni zapoznać się z aktualnymi informacjami o warunkach panujących na ścieżkach turystycznych.

Slowa kluczowe: Wyspy Liparyjskie (Eolskie), aktywność wulkaniczna typu Stromboli, przyczyny erupcji, skaty i rzeźba wulkanu, dostepność turystyczna

\section{Introduction}

Active volcanoes can become major tourist destinations visited by people for a variety of reasons. Some people would like to experience scenic beauty close to nature, while others have the ambition to climb a volcano, take photos, or learn about the surrounding geodiversity. Most of the tourists would like to explore various volcanic features such as eruptions, lava flows, fumaroles, geysers, boiling mud, and hot springs.

A large impact on volcanic tourism is related to volcanic eruptions. An example is the eruption of Eyjafjallajökull (2010) in Iceland, when during a one month period, tourists watched both the fiery fissures and vast ash clouds from a close proximity. From the tourist's point of view, the best forms of volcanic activity are long-lived eruptions, when people can observe the activity from immediate vicinity and in relative safety. Such examples are displayed in the Hawaiian and Strombolian eruptions.

In this paper, we present one of the most popular active volcanos in the world, the Stromboli Volcano (Fig. 1), that has been almost continuously active for 1300 yrs (Rosi et al., 2000). Anyone who sailed to Stromboli would be able to see the explosions at any time, because the ejection of bombs, black scoria, lapilli and ash occur every 10-20 min, accompanied by continuous degassing (Barberi et al., 1993).

\section{Location and access}

Stromboli is the northernmost island of the Aeolian Arc, located in the Southern Tyrrhenian Sea in the central Mediterranean. The distance to the mainland is $54 \mathrm{~km}$, while it is $240 \mathrm{~km}$ to Naples (Napoli) and $55 \mathrm{~km}$ to Sicily. The nearest of the other Aeolian Islands is Panarea Island (Fig. 2), $18 \mathrm{~km}$ to the Southwest. 

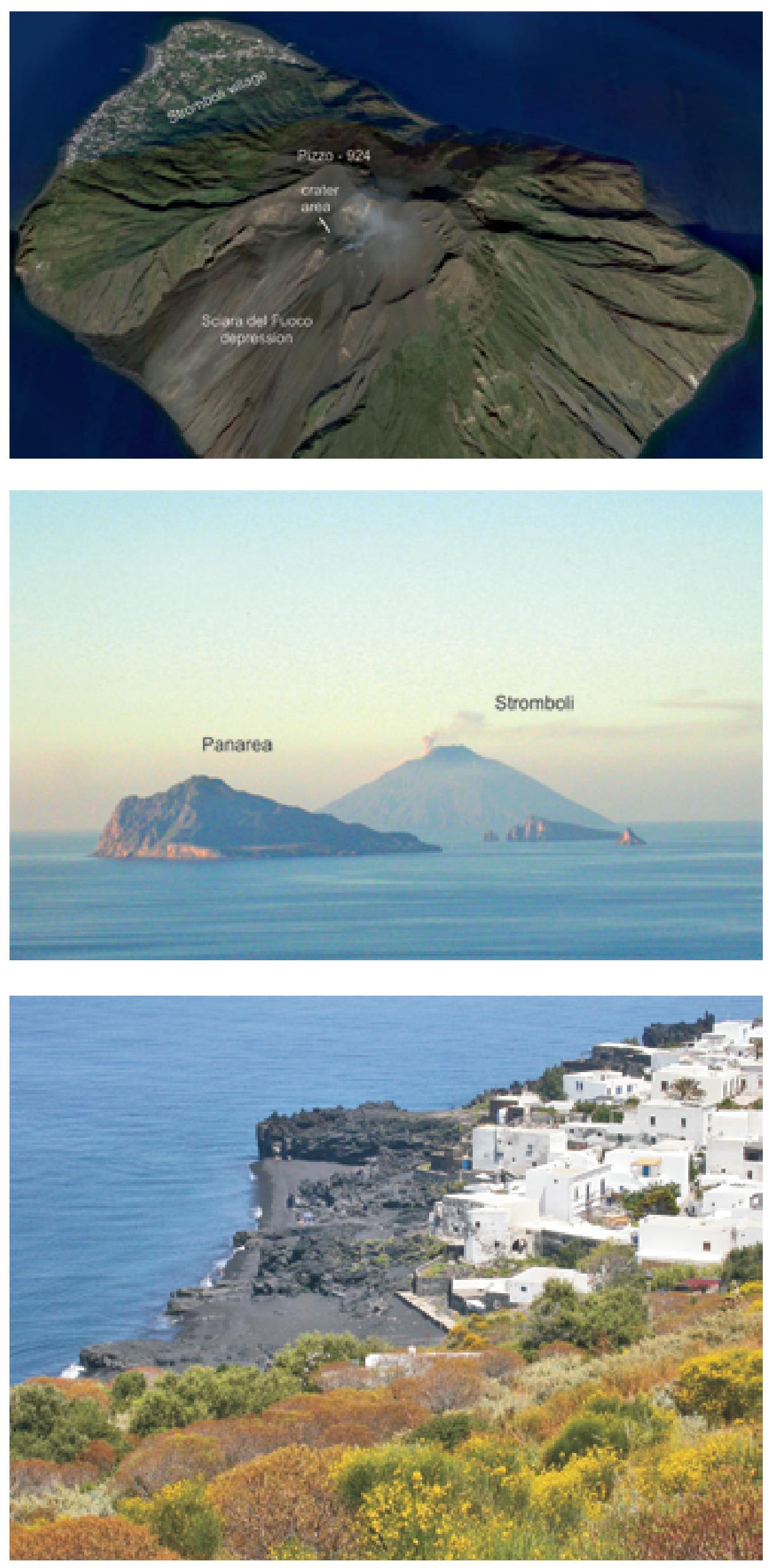

Fig. 1. Image of the Stromboli Vulcano (source: Google Maps) - Wulkan Stromboli (źródło: Google Maps)

Fig. 2. Panarea (inactive volano) and Stromboli islands within the eight Aeolian Islands, photo K. Bąk - Panarea i Stromboli - dwie z ośmiu wysp wulkanicznych w obrębie łuku Wysp Liparyjskich (Eolskich), fot. K. Bąk

Fig. 3. Northern part of Stromboli village (Piscita) lying on basaltic lavas, photo K. Bąk - Północna część Stromboli z zabudowaniami Piscita położonymi na lawach bazaltowych, fot. K. Bąk 
The volcano rises from a depth of about $2000 \mathrm{~m}$ below sea level and elevates up to $924 \mathrm{~m}$ above sea level (Fig. 1). Tourist paths allow one to reach the height of $918 \mathrm{~m}$. From this height, tourists may observe the active crater $150 \mathrm{~m}$ below.

There are two settlements on the island: Stromboli in the Northeast (Fig. 3), with a boat jetty for hydrofoils and a small village of Ginostra in the West (Fig. 4), where the ships leave travelers on boats, close to the boat jetty. No cars may be taken to the island. Distances are short enough for walking. Transportation between the two villages of Stromboli and Ginostra is by ship, hydrofoil or small boats operated by locals. Hotels in Stromboli village use small vehicles to pick up guests and baggage from a boat jetty. The total permanent population of the island is ca 350 residents, however, during the summer months, there are many hotel employees and tourists there.

Stromboli is normally reached from Napoli by ship (by hydrofoil in the summer), from Milazzo (Sicily) and the other Eolian Islands by ship and hydrofoil (all year round). Between June and September, there are more routes and more services including hydrofoils from Reggio Calabria and Vibo Valentia in mainland Italy, and hydrofoils from Messina and Palermo in Sicily. SIREMAR (ships and hydrofoils), SNAV (hydrofoils), USTICA LINES (hydrofoils) and ALILAURO (hydrofoils) operate there. A ferry from Napoli takes ten hours to Stromboli, but hydrofoil - just four and a half hours.

\section{Geology and geomorphology}

The geochemistry of volcanic rocks and data from deep seismicity (Milano et al., 1994) led researchers to interpret the Aeolian Islands as a volcanic arc related to the active subduction beneath the Calabrian Arc (e.g. Mantovani et al., 1997; Falsaperla et al., 1999; Peccerillo, Panza, 1999; Fig. 5). In such interpretation, Stromboli, as one of the Aeolian volcanoes is located between the Southern Tyrrhenian Sea backarc basin (Marsili ocenic basin) and the Calabrian Arc forearc region (Boccaletti et al., 1984). It is placed on a $15-20 \mathrm{~km}$ thick continental crust (Gillot, Keller, 1993).

The volcano is characterized by composite structures. Effusive and explosive activity produced thick lava flows and domes and thick pyroclastic sequences (Fig. 6). Its subaerial part was built in the last $100 \mathrm{ky}$ through six main periods of its activity (Hornig-Kjarsgaard et al., 1993; Cortes et al., 2005; Francalanci et al., 2013), which from the oldest to the youngest are called as follows: Paleostromboli I, II, III (100-35 ky), Vancori (26-13.8 ky), Neostromboli (13.8-5.6 ky) and Recent periods (5.6 ky - present) (Fig. 7). Several collapses alternated with the periods of activity, leading to the formation of several Amphitheatre depressions (e.g., Hornig-Kjarsgaard et al., 1993; Fig. 7).

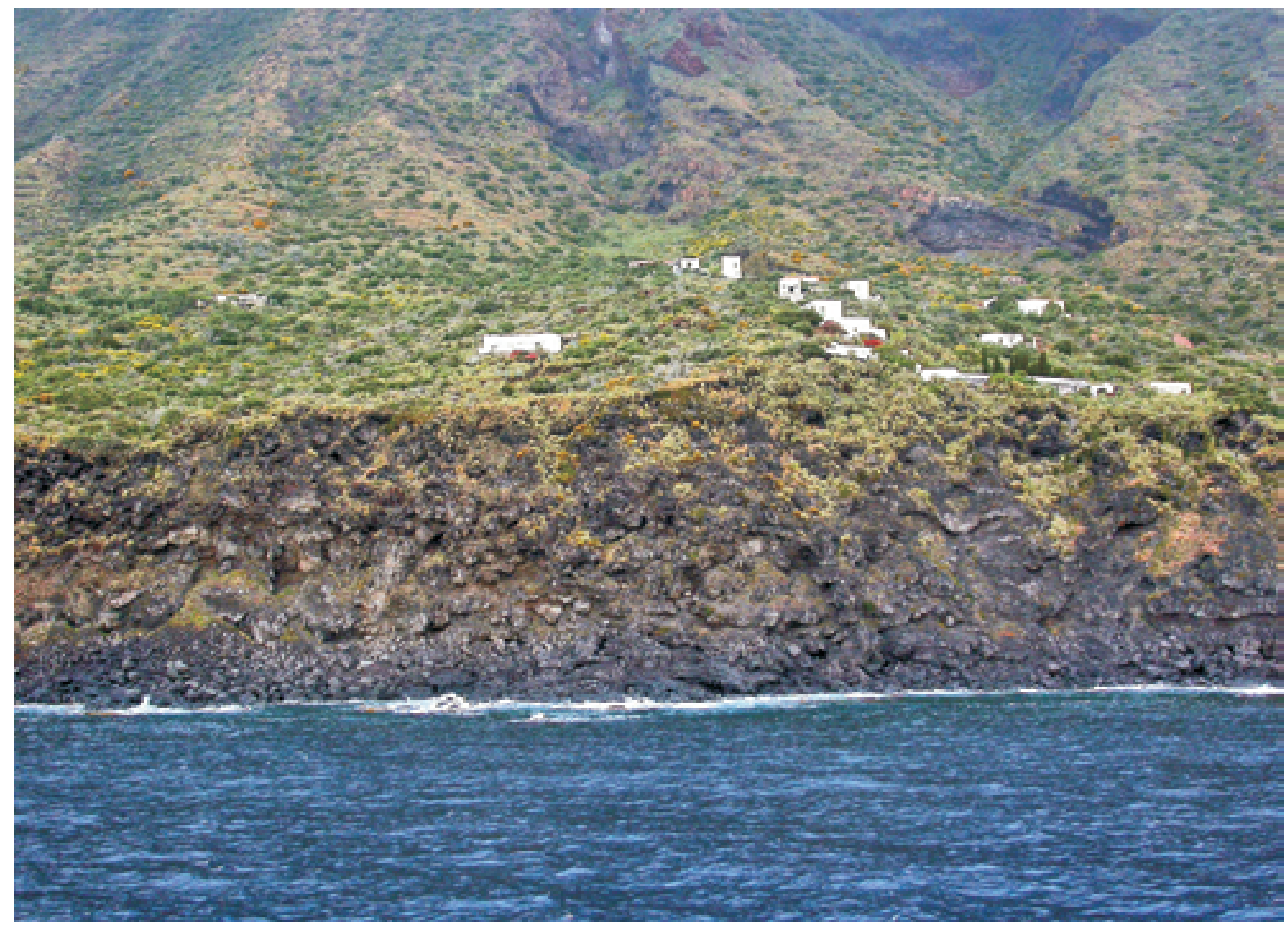

Fig. 4. Ginostra village lying above cliffs of the western part of the island, photo M. Bąk • Zabudowania wsi Ginostra położonej ponad klifem w zachodniej części wyspy, fot. M. Bąk 

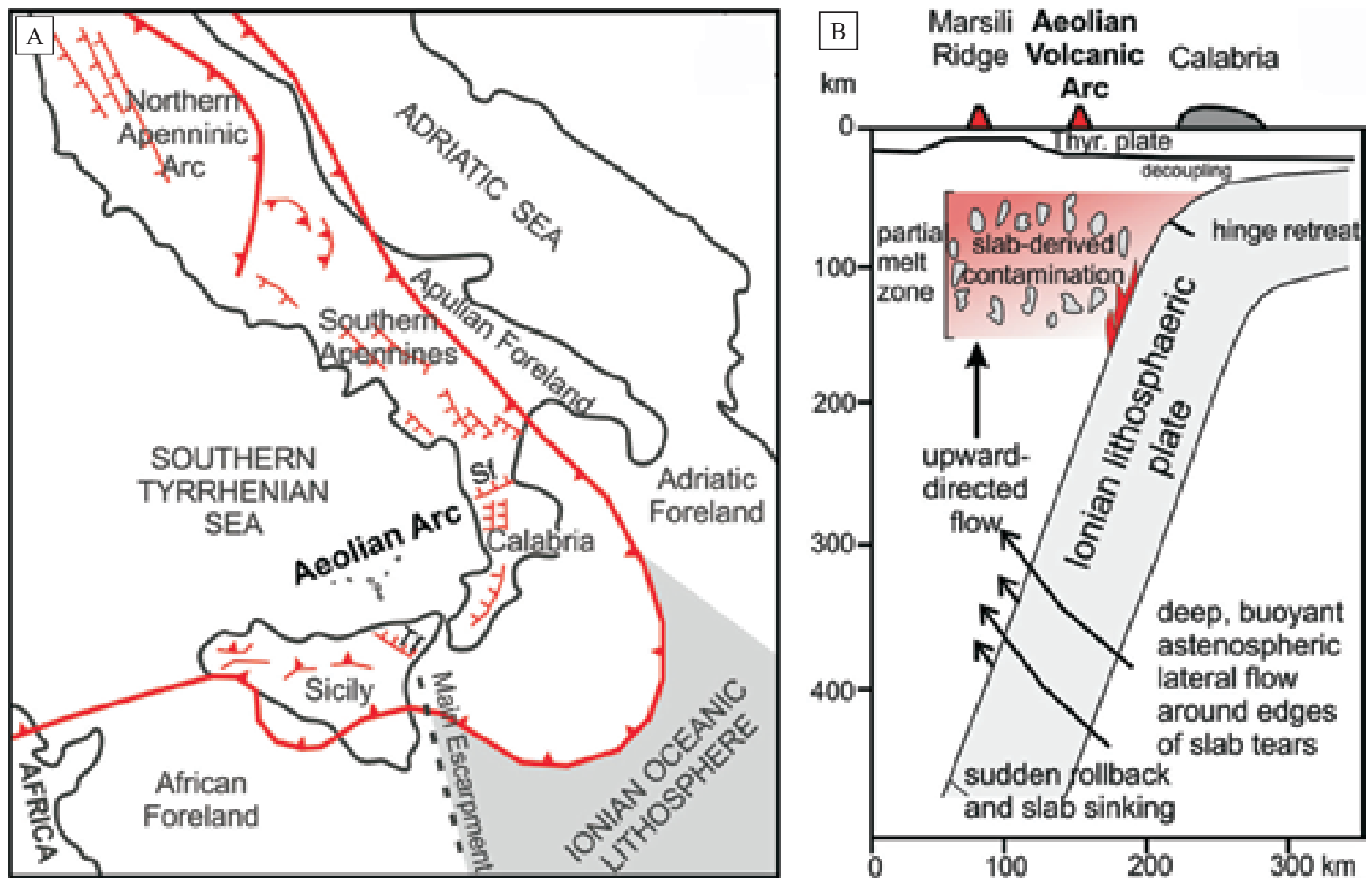

Fig. 5. Sketch map of the main structural elements of the Italian Peninsula and its surroundings (after Marani, Trua, 2002). A - Red lines represent main thrust fronts; outer front of the Apenninic-Maghrebide orogenic system - with red triangles, hatched line - main extensional faults; $\mathrm{Tf}$ - Taomina fault; $\mathrm{Sf}$ - Sanginetto fault. B - Sketch section showing the subduction of the Ionian lithosphere with position of Aeolian Volcanic Arc and crustal thickness of the Tyrrhenian plate (modified after Marani, Trua, 2002) - A - Schematyczna mapa głównych elementów strukturalnych półwyspu włoskiego i przyległych obszarów (za Marani, Trua, 2002). Linie czerwone - główne nasunięcia tektoniczne: z czerwonymi trójkątami - główne nasunięcie apenińsko-magrebskie (NW afrykańskie), z czerwonymi ząbkami - główne uskoki ekstensyjne; Tf - uskok Taomina, Sf - uskok Sanginetto. B - Schematyczny przekrój pokazujący subdukcję płyty jońskiej i będący jej efektem łuk Wysp Liparyjskich; uwzględniono miąższość płyty Morza Tyrreńskiego (zmienione za Marani, Trua, 2002)

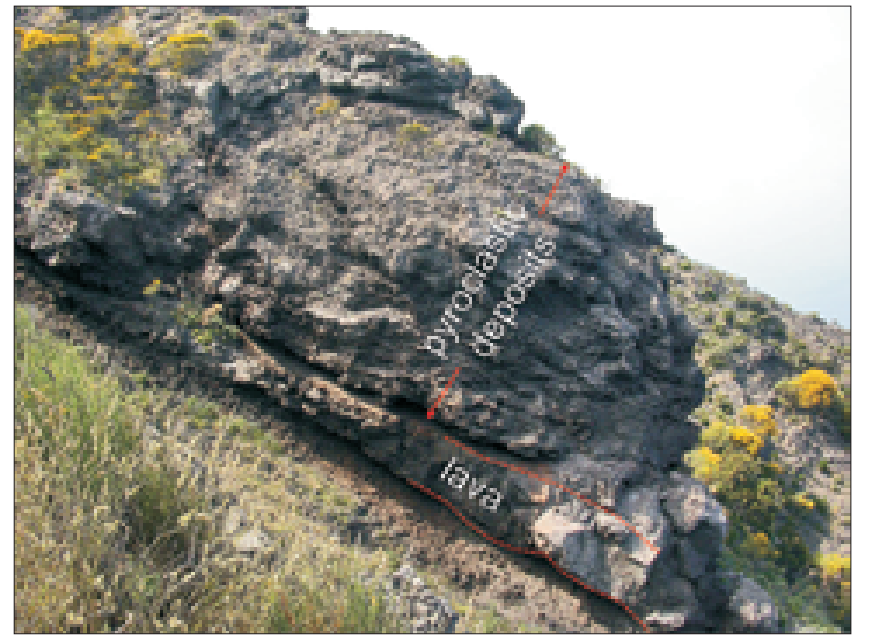

Fig. 6. Crest of the Sciara del Fuoco depression with typical for a stratovulcano repeated sentence of lava material and pyroclastic deposits, photo K. Bąk • Krawędź depresji Sciara del Fuoco z widoczną serią osadów lawowych i materiału piroklastycznego, typową dla stratowulkanu, fot. K. Bąk
Some of them correspond to older periods of three summit caldera-type collapses and one flank collapse. The lateral collapses occurring on the NW flank of Stromboli started from 13 ka onwards (Tibaldi, 2001; Tibaldi et al., 2003). Such types are represented by the Sciara del Fuoco, a NESW elongated depression, that is the main unstable flank of the recent Stromboli volcano, with a slope of $40^{\circ}$ and an extension of $700 \mathrm{~m}$ b.s.l. (Tibaldi, 2001).

Stromboli is surrounded by a relatively flat surface at shallow depth $(<150 \mathrm{~m}$ b.s.l.; Fig. 8). This erosive shelf plateau has been interpreted as the Late Pleistocene abrasion platform (Gabbianelli et al., 1990; Favalli et al., 2005). This platform is missing within the areas of more recent activity i.e. westward offshore from Sciara del Fuoco depression. The formation of the abrasion platform was related to the cycle of Pleistocene glacio-eustatic changes occurred at around $20 \mathrm{ka}$ ago (2nd isotopic stage). The platform also includes an old eruptive center, presently represented by the small islet Strombolicchio (as a neck), located NE of Stromboli (Fig. 9). It contains remnants of a huge edifice in this area dated 204 ka ago (Gillot, Keller, 1993). 


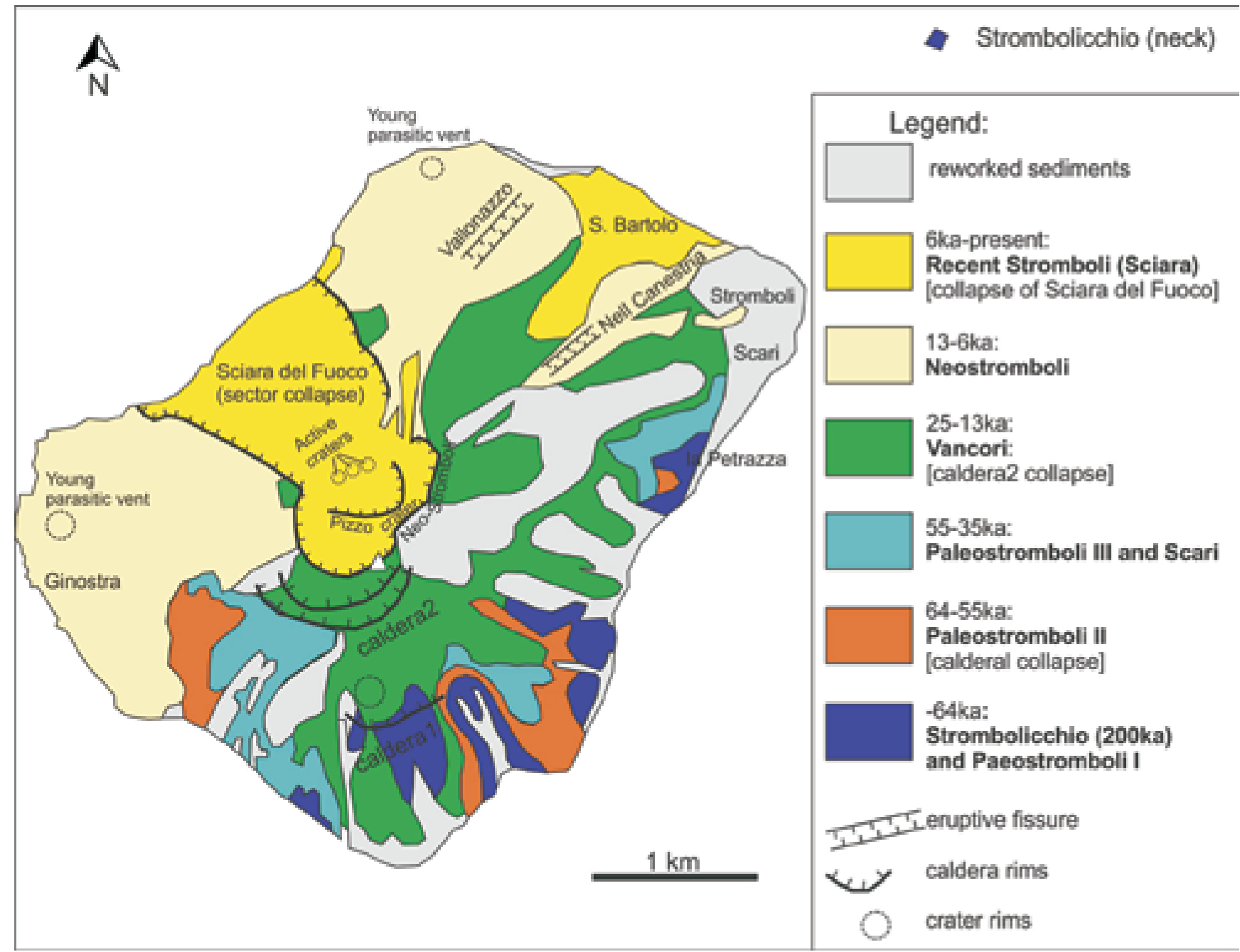

Fig. 7. Geologic map of the Stromboli with distribution of the major volcanic units (after Keller et al., 1993; Guest et al., 2003) • Mapa geologiczna Stromboli z podziałem na główne jednostki wulkaniczne, związane z wiekiem wulkanizmu (na podstawie Keller et al., 1993; Guest et al., 2003)

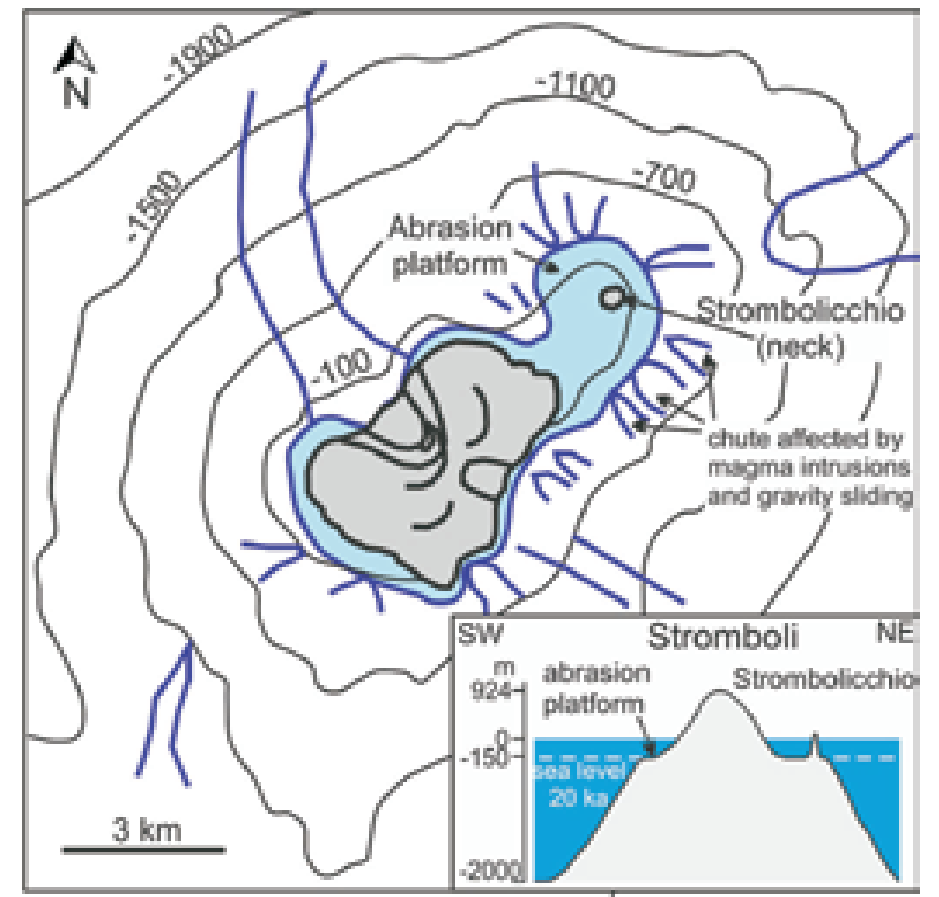

Fig. 8. Schematic geomorphological map and cross section through the Stromboli; note numerous elongated submarine chutes (between blue lines) induced by magma intrusions and gravity sliding and an occurrence of abrasion platform around the subaerial part of the cone with neck after older volcanic activity (204 ka) of this area (its subaerial part is named Strombolicchio) (summarized after Tibaldi, 2001; Favalli et al., 2005) - Schematyczna mapa geomorfologiczna i profil poprzeczny przez Stromboli; zauważ liczne podmorskie żleby (pomiędzy niebieskimi liniami), związane z procesami tworzenia szczelin na stoku wulkanu, przemodelowane przez spływy materiału piroklastycznego i osuwiska; zauważ również obecność platformy abrazyjnej wokół powierzchniowej i podpowierzchniowej części stożka oraz obecność neku, który dokumentuje starszą działalność wulkaniczną sprzed 204 tys. lat; jego powierzchniowa część to wyspa Strombolicchio (na podstawie Tibaldi, 2001; Favalli et al., 2005) 


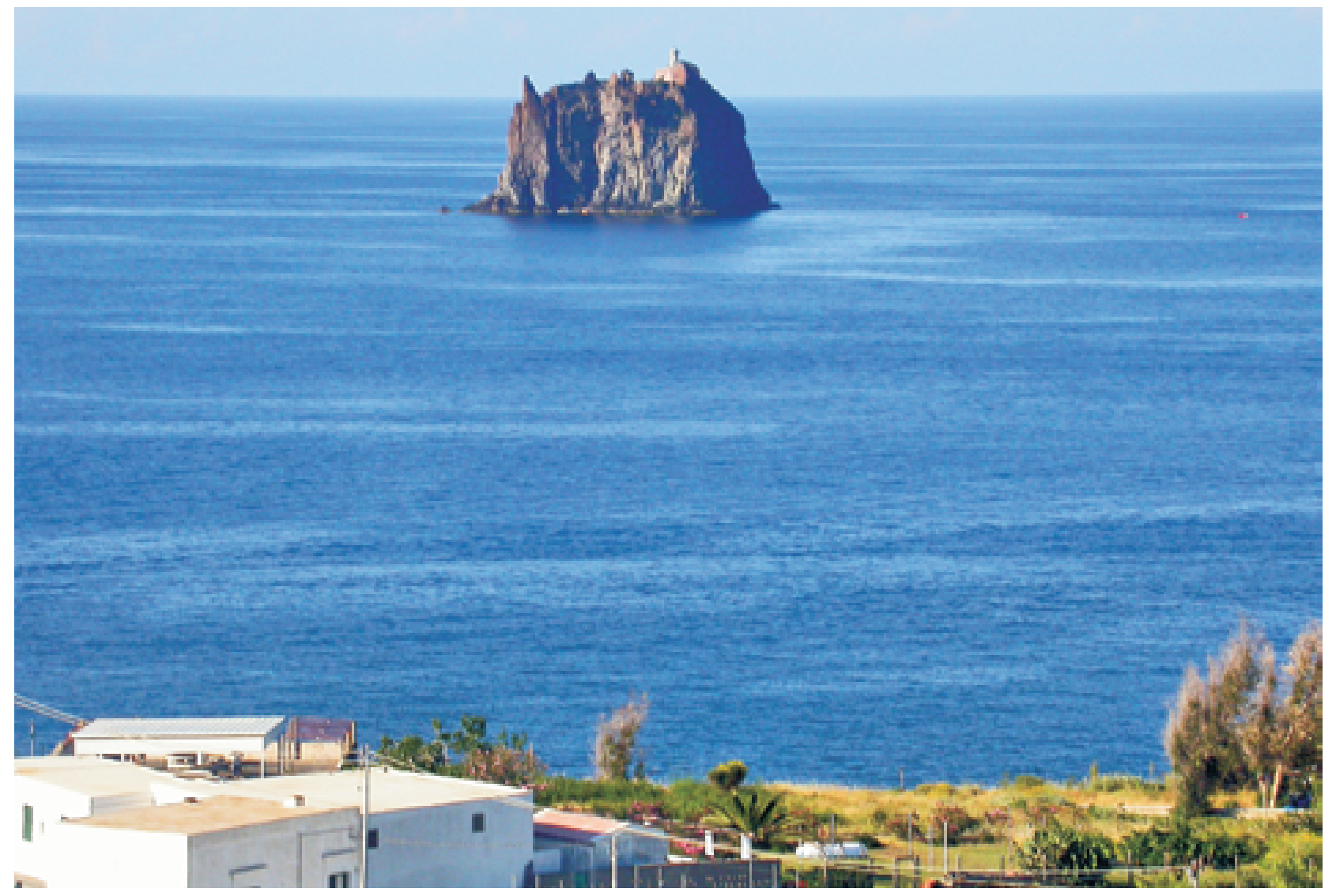

Fig. 9. Islet Strombolicchio located NE of Stromboli - a neck from old (204 ka) eruptive center in this area, composite, photo M. Bąk • Mała wyspa Strombolicchio położona na NE od Stromboli - nek wulkaniczny związany z wulkanizmem sprzed 204 tys. lat, fot M. Bąk

The composition of eruptive products is variable, ranging from calc-alkaline (mainly basaltic-andesites) and high$\mathrm{K}$ calc-alkaline (high-K basalts to high-K andesites) to shoshonitic (shoshonitic basalts to trachytes) (e.g., Petrone et al., 2009; Vezzoli, Corazzato, 2016). It is related to the still active subduction of the Ionian Plate beneath the Calabrian Arc (e.g., Mantovani et al., 1997; Falsaperla et al., 1999;

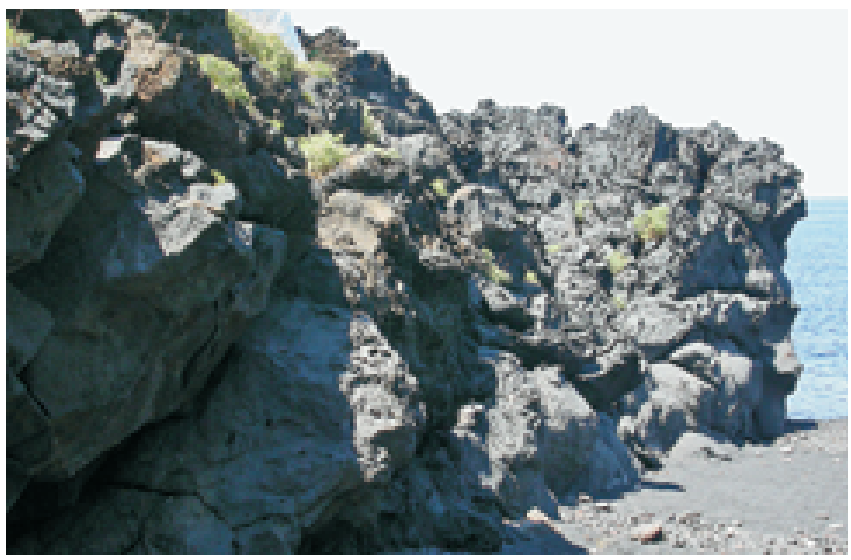

Fig. 10. Pillow lavas (shoshonitic basalts) from the Recent (since 6 ka) stage of the Stromboli; cost of Piscita, photo K. Bąk • Lawy poduszkowe $\mathrm{z}$ szoszonitowych bazaltów, powstałe w czasie ostatniego okresu wulkanizmu na Stromboli, który rozpoczął się 6 tys. lat temu, widoczne na północnym wybrzeżu wyspy (przysiółek Piscita), fot. K. Bą
Peccerillo, Panza, 1999). Consequently, magma series are products of different degrees of partial melting of a mantle wedge heterogeneously affected by subduction-related metasomatism (Tommasini et al. 2007; Martelli et al., 2014).

The rocks of the Recent period of activity, younger than $5.6 \mathrm{ka}$ are high-K and shoshonitic basalts (Francalanci et al., 1999 ; Figs 10, 11).

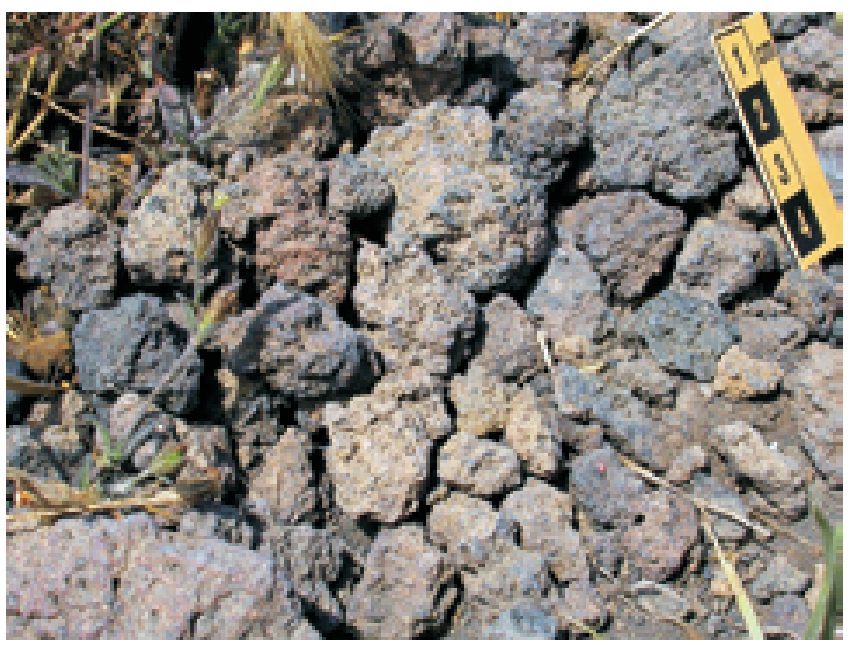

Fig. 11. Lapilli form Recent activity of Stromboli; close to the crest of the Sciara del Fuoco, photo M. Bąk - Lapilli, materiał piroklastyczny ze współczesnych erupcji Stromboli; obok krawędzi depresji Sciara del Fuoco, fot. M. Bąk 


\section{Present-day activity}

Depending on the period of stay at Stromboli, tourists may observe three types of eruptive activity (summary in Rosi et al., 2013): a) normal Strombolian activity (Figs 12, 13), b) violent explosions (Strombolian paroxysms; Fig. 14 - grey and green bars), and c) lava flow emissions (Fig. 14 - red bars).

Normal Strombolian activity consists of rhythmic, mild explosions lasting for a few seconds, with ejections of lapilli and bombs, ash and lithic blocks. Frequencies of eruption range between 7 and 17 events per hour (Delle Donne et al., 2006). The duration of emissions ranges from 4 to $30 \mathrm{~s}$ (Delle Donne et al. 2006; Patrick et al., 2007).

Ejecta rise up to 50-400 m above the vents (Patrick et al., 2007) and ballistic clasts fall anywhere in tens of metres from each other and in 200-250 m from the vents. Solid fragments ejected in each explosion have a mass up to $6,000 \mathrm{~kg}$ (Ripepe et al., 2002; Patrick et al., 2007). During each explosion, gas emission has been estimated as $6-19 \mathrm{~kg} / \mathrm{s}$ (Allard et al., 1994). The average eruption rate for normal Strombolian activity was estimated as $0.01 \mathrm{~m}^{3} /$ second. It corresponds to about $300.000 \mathrm{~m}^{3}$ during one year (Marsella et al. 2012).
Two main types of explosions occur during the normal activity (Patrick et al., 2007): ballistic-dominated explosions with negligible ash production, and ash-dominated explosions. Explosions of Stromboli occur from three crater sectors. They show different types of activity at the same time, whereas a given crater may show the same type of activity for weeks or months (Patrick et al., 2007). These active craters could be observed by tourists from Pizzo Sopra la Fosa (918 $\mathrm{m}$ a.s.1.).

For such type and dynamics of explosive regimes as described above, G. Mercalli (1881) adopted the term 'Strombolian' that is now commonly used in volcanology.

Violent explosions which are also named Strombolian paroxysms are characterized by the almost simultaneous involvement of several vents with the fallout of heavy materials. Violent explosions eject the juvenile scoriaceous fragments and highly vesicular fragments called 'golden pumice' (up to $90 \%$ vol. of voids), which represent gas-rich, low-porphyricity pumices (high-K basalts) with crystals of clinopyroxene, olivine and plagioclase (up to $30 \mathrm{vol} \%$ ) (e.g., Metrich et al., 2010; Allard, 2010; Pichavant et al., 2011; Pompilio et al., 2012).

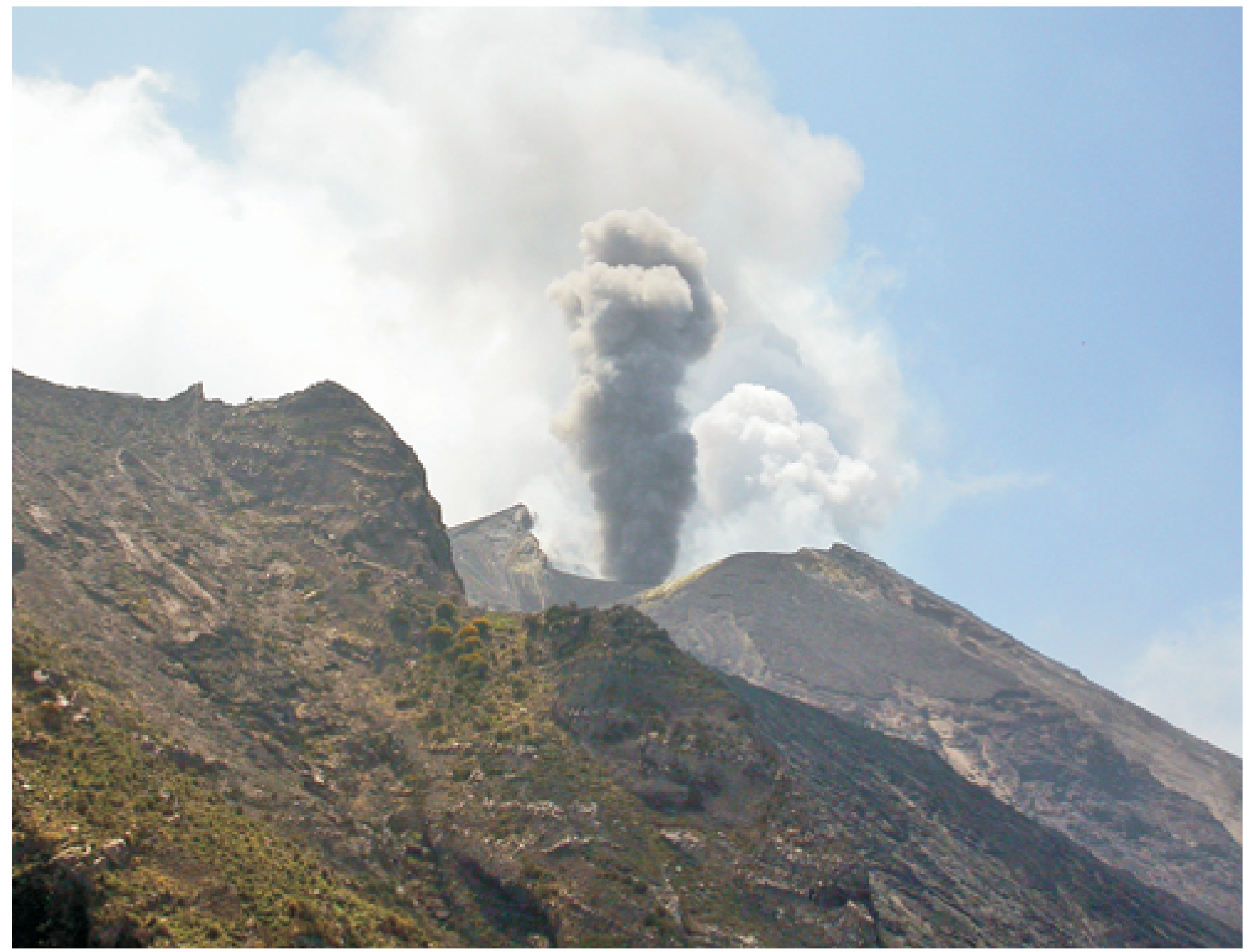

Fig. 12. Normal explosion lasting a few seconds with ejection of lapilli, bombs, ash, and gas emission; ejecta rise $250 \mathrm{~m}$ above the crater, photo M. Bąk - Przykład tzw. normalnej eksplozji wulkanu, trwającej kilka sekund, w czasie której wyrzucana jest lawa, w postaci lapilli, bomb i popiołów, z towarzyszącą emisją gaz wulkanicznych do wysokości około $250 \mathrm{~m}$ powyżej krateru, fot. M. Bąk 

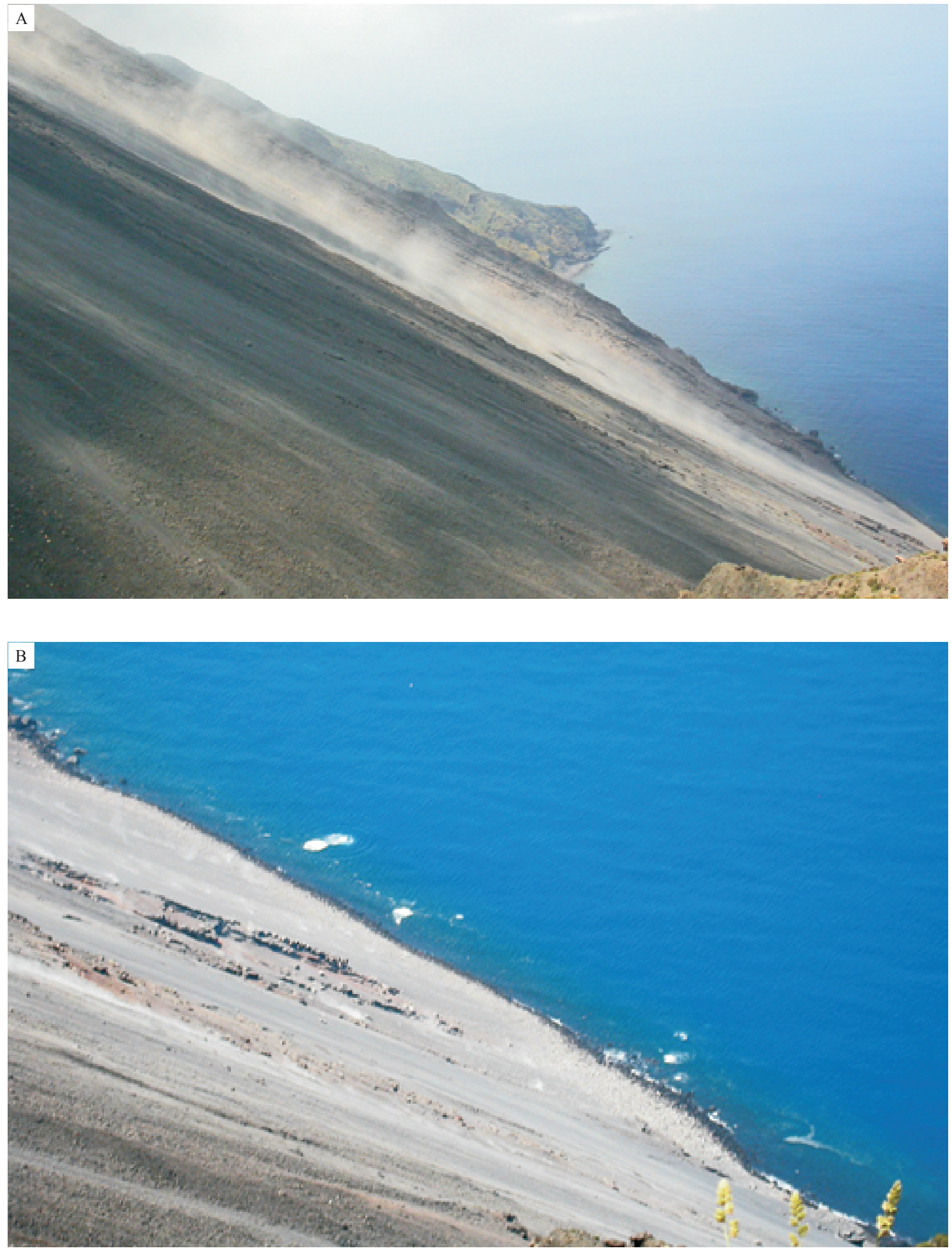

Fig. 13. Volcanic bombs carried in saltation along the floor of the Sciara del Fuoco depression (A) and falling into the Tyrrhenian Sea (B); photo is taken 10-15 seconds after explosion, photos M. Bąk • Bomby wulkaniczne opadające ruchem skokowym (w tzw. saltacji) po powierzchni stoku wulkanu w obrębie depresji Sciara del Fuoco (A) i wpadające do Morza Tyrreńskiego (B); zdjęcia wykonano kilkanaście sekund po eksplozji, fot. M. Bąk 


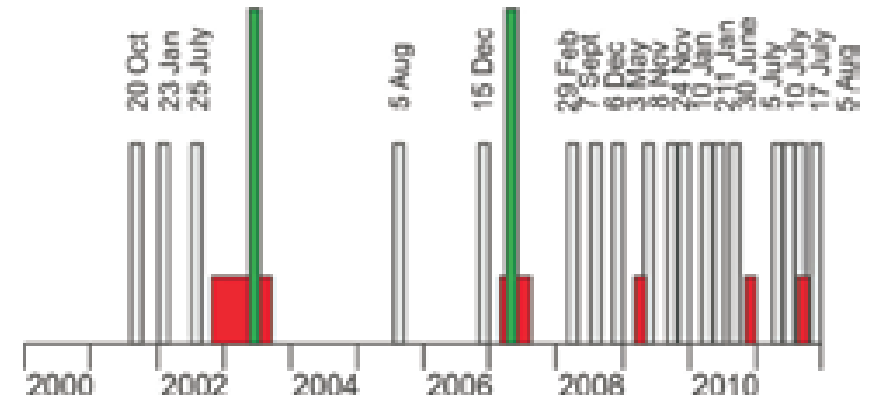

Fig. 14. Major explosions (grey rectangle), large-scale paroxysms (green rectangle), and lava flows (red rectangle) occurring at Stromboli from 2000 to 2011 (after Marsella et al., 2012; Rossi et al., 2013) - Diagram czasowy (od roku 2000 do 2011) pokazujący okresy wystąpienia dużych eksplozji (kolor szary), wielkoskalowych paroksyzmów (kolor zielony) i wylewów lawy (kolor czerwony) (zestawione na podstawie: Marsell et al., 2012; Rossi et al., 2013)

Among violent explosions, typical events consist of jets of gas and pyroclasts, lasting for 30-40 seconds and a few hundred metres high, which rapidly (tens of seconds) evolve into short-lived plumes reaching a height of about $1 \mathrm{~km}$ (Rosi et al., 2013). Seventeen events of this magnitude have been documented between 2002 and 2011 (1.7 episodes per year; Rossi et al., 2013; Fig. 14). Every few decades, large-scale paroxysms with impulsive explosions lasting for a few minutes occur there and disperse pyroclasts up to a few kilometres from the vents, followed by a minutes-lasting period of vigorous degassing (Rosi et al. 2006; Pistolesi et al. 2011). The explosions involve all active vents and eject metre-sized scoria bombs and blocks up to $2 \mathrm{~km}$ from the craters, with the ash-gas plume that rises several kilometres (Rosi et al., 2013). They are accompanied by the formation of compressive waves (shock waves) and cannon-like detonations, that can break windows in houses in the villages of Stromboli and Ginostra.

The recent large-scale paroxysms occurred on 5 April 2003 and 15 March 2007, during which the fallout of incandescent blocks on vegetated areas set off wildfires. Smallscale pyroclastic flows and hot avalanches were also observed (e.g., Pistolesi et al., 2011).

Lava flow emissions can occur at Stromboli as: smallscale $\left(1000 \mathrm{~m}^{3}\right)$ intra-crater flows, intermediate-volume (up to $10^{6} \mathrm{~m}^{3}$ ), short-lived flows (about 1 day as in 1959, 1993 and 2011) when lavas form tongues in the Sciara del Fuoco depression, and fairly large volume flows $\left(10^{7} \mathrm{~m}^{3}\right)$ fed from fissures, sometimes active for months, descending the Sciara del Fuoco depression and reaching the coast, where they can form lava deltas (Rosi et al., 2013). Three last eruptive crises lasted from 28th December 2002 to 22th July 2003, from 27th February 2007 to 2nd April 2007, and from 6th August 2014 to 17th November 2014. No deep submarine eruption related to the present activity has been documented, except for fresh pillow deposit of unknown age at $2300 \mathrm{~m}$ b.s.l. (Di Roberto et al. 2008). Higher frequency and volume of effusive eruptions were documented starting from the first half of the past century than the second half (Marsella et al., 2012). Two large effusive eruptions occurred in the last decade (2003 and 2007) are characterized by high effusion rates $\left(2.6 \cdot 10^{6} \mathrm{~m}^{3} \mathrm{~s}^{-1}\right)$.

\section{Causes of Strombolian activity}

The plumbing system of Stromboli is characterized by a magmatic reservoir, located at 5-10 km depth, where a low porphyritic magma is generated (cf. Francalanci et al., 2005; Metrich et al., 2010; Fig. 15). This deep reservoir is connected to the vents trough an intermediate storage zone placed at $3 \mathrm{~km}$ depth, at the base of the volcanic apparatus. This shallow plumbing system behaves as an elongated degassing cell (with size $\sim 12 \pm 3 \mathrm{Mm}^{3}$; Allard et al., 2008). From this level, a convective regime allows degassing and crystallisation processes with the production of high porphyritic magma which promotes typical Strombolian activity (e.g., Francalanci et al., 2005; Aiuppa et al., 2010; Metrich et al., 2010).

Two models were proposed to explain Strombolian explosions (summary in Parfitt, 2004): a collapsing foam model and a rise-rate-dependent model. In the collapsing foam model (CF), magma is stored within the area, like a magma chamber or a dike system, at a depth $(3 \mathrm{~km})$ where gas bubbles can exsolve from magma. These gas bubbles rise and accumulate at the roof of storage area and become closepacked into a foam layer. When the foam layer reaches critical thickness, it becomes unstable and collapses, the bubbles coalescing to form a gas pocket. The gas pocket then travels up the conduit system in slug flows and bursts at the magma free surface. In this model, Strombolian eruptions represent repeated partial foam collapse events, related to the relatively high viscosity of liquid, where the foam collapses only partially and forms a series of smaller gas pockets (e.g., Vergniolle, Jaupart, 1986; Jaupart, Vergniolle, 1989).

In the rise-rate-dependent model (RSD), the Strombolian eruptions are assumed to be the result of bubbles segregation and coalescence process (summary in Parfitt, 2004). If the rise speed of magma is relatively low (below $0.01 \mathrm{~m} / \mathrm{s}$; Parfitt, Wilson, 1995; Fig. 16), gas bubbles within the magma will rise upwards through the overlying magma and can segregate from magma in which they are formed. As the rise speed of a bubble depends partly on its size, a runaway situation can be achieved, in which an initially larger bubble, rising faster than the smaller bubbles, overtakes the smaller bubbles and, in doing so, coalesces with them. Such coalescence can lead to even a single large bubble that is as wide as the conduit rising through the overlying magma. In an open system of Stromboli, cooling at the top of magma column causes the development of a 'skin' with a finite strength. The skin strength will depend on how much cooling occurs before the arrival of large bubbles. If the interval between bubble arrival is short enough, each bubble will updome the thin skin and burst through the top of magma column with a minimal delay. If the interval between the arrival of giant bubbles is longer, the skin will cool and thicken and then more than one bubble may arrive and become trapped before sufficient pressure is built up in an accumulating gas pocket to break through the skin. The short time interval between explosions suggests that the strength of this skin is never very great. 


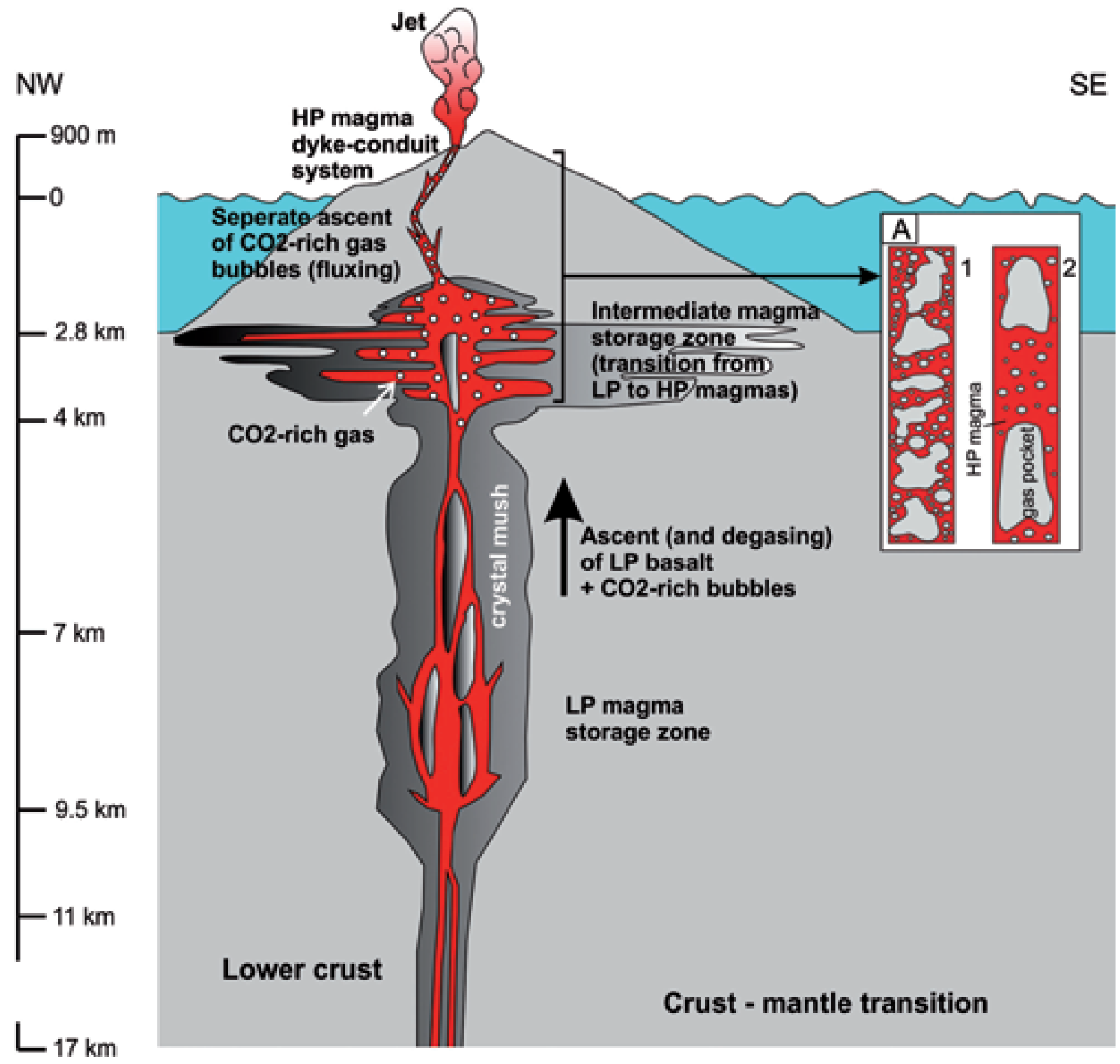

Fig. 15. Sketch cross-section of the Stromboli plumbing system (after Aiuppa et al., 2010; simplified) with various of gas pockets ascending vertical plumbing system (Tadeucci et al., 2015). A - The scheme of various gas pockets presents the results of experiment in a $7.5-\mathrm{cm}$ diameter laboratory pipe: 1 - an initial gas pocket may cause an individual ejection pulse, followed at regular intervals by similar ones; 2 - long gas pockets may fragment before or during bursting, causing transient blockages of the vent and multiple, closely repeated pulses. - Schemat pokazujący przekrój przez Stromboli z położeniem dwóch systemów komór zasilających (storage zones), szczelin i komina (na podstawie Aiuppa et al., 2010; uproszczono) z różnym typem magmy bazaltowej (LP i HP) oraz pęcherzy gazu bogatego $\mathrm{w} \mathrm{CO}_{2}$ wędrującego ku górze przez wewnętrzny system lawowy stożka (na podstawie Tadeucci et al., 2015). A - Schemat różnej wielkości pęcherzyków gazu wędrujących ku górze, będący przykładem eksperymentu laboratoryjnego w szklanym cylindrze o średnicy $7,5 \mathrm{~cm}$, który wyjaśnia mechanizm powtarzających się częstych eksplozji: 1 - pojedyncze eksplozje są związane z ruchem magmy ku górze, która zawiera tzw. kieszenie gazowe, wędrujące w pewnej odległości od siebie, będące w stanie rozerwać „korek” powstały z szybko gęstniejącej przy powierzchni magmy; 2 - wędrujące ku górze duże (długie) kieszenie gazowe mogą w trakcie tego ruchu rozdrobnić się na mniejsze, powodując przejściowe zablokowanie przepływu zgazowanej magmy i zmienić (wydłużyć) rytm częstości eksplozji.

Both models are similar (Parfitt, Wilson, 1995), however, in the RSD model progressive segregation occurs because of the low rise speed of magma beneath the eruptive vent. In turn, the $\mathrm{CF}$ model assumes that gas segregation occurs at depth in a magma chamber or storage zone (ca. $3 \mathrm{~km}$ at Stromboli) and that accumulation of this gas as a foam layer and its partial collapse give rise to a slug of gas which rises up through the vent system and bursts through the top of magma column. 


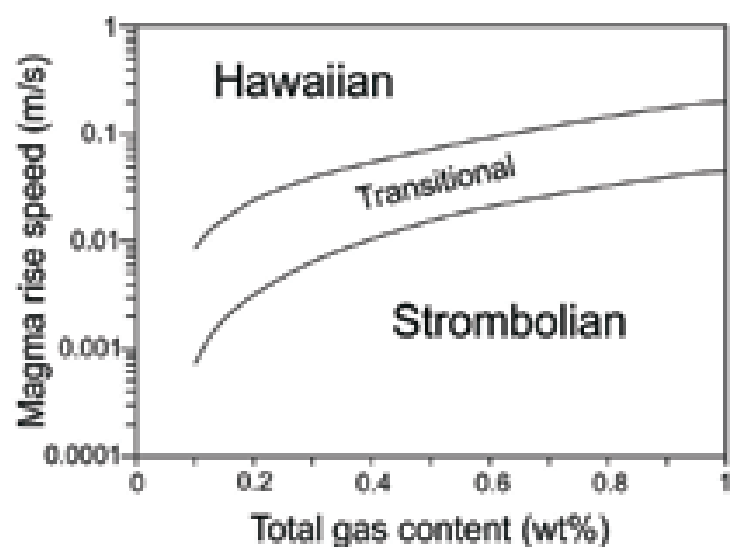

Fig. 16. Diagram showing the relationship between rise speed magma and total gas content for Strombolian and Hawaiian activities (after Parfitt, Wilson, 1995) - Diagram pokazujący typ eksplozji wulkanizmu bazaltowego w relacji do prędkości magmy i objętości gazów wędrujących ku górze w wewnętrznym systemie magmowym (za Parfitt, Wilson, 1995)

\section{Crater area and types of 'normal' eruptions}

The typical Strombolian activity takes place from several vents (from 3 to 9; Harris, Ripepe, 2007) located within the crater area (Fig. 17). It consists of an NE-SW elliptical depression, so-called crater terrace, with axes $\sim 300 \mathrm{~m}$ long and $\sim 150 \mathrm{~m}$ wide lying at $\sim 800 \mathrm{~m}$ a.s.1., ca 100-130 m below the summit of volcano (Pizzo Sopra la Fossa - 924 m a.s.1). During periods of intense activity, the crater terrace grows due to accumulation of pyroclastic material and intra-crateric lavas (Rosi et al., 2013). Explosions in three main areas of the crater terrace (Fig. 17) during normal activity form cones and hornitos topped by narrow outlets, however, more energetic eruptions conversely dismantle parts of cones and hornitos. Following the large-scale paroxysms and lava effusion, like those in 2007, the crater terrace enlarges due to progressive collapse of the walls of the central conduit (Neri, Lanzafame, 2009). Such large-scale paroxysms in 1930 caused the lowering of the crater terrace to about $70 \mathrm{~m}$ (after Rosi et al., 2013).

Three types of explosions from the crater area (summary in Leduc et al., 2015) were defined during the 'normal' activity period of Stromboli: ballistic (bomb) dominated, ash dominated and gas dominated (Fig. 18). Ballistic dominated eruptions are related to large proportions of degassed and stagnant material in the shallow system mixture. During the eruption, bombs and lapilli are passively entrained by the gas jet (Harris et al. 2013) and may result from the failure and fragmentation of a high-viscosity degassed cap (Gurioli et al. 2014).

Gas dominated eruptions are associated with a fresh conduit, the removal of a degassed volume having caused the free surface (and explosion source) to migrate to a deeper level (Leduc et al., 2015). These events tend to lack particles due to the small amount of juvenile material available for accidental entrainment with the gas burst. The explosion depth is more than $250 \mathrm{~m}$ and is characterized by a high-velocity emission (150-250 m/s; Leduc et al., 2015).
Ash dominated eruptions may originate from one of two sources (Patrick et al., 2007). The first source is grinding, milling, and recycling of loose material that avalanches into the vent. The second source is caused by rheological changes in the uppermost magma column, where the increase of magma viscosity may lead to fragmentation at a finer scale to create ash. These eruptions are the function of overpressure coming from a bursting slug. Type 'a' on Figure 18 involves higher bubble overpressures to send juvenile and recycled ejecta to greater heights during higher energy eruptions (Patrick et al. 2007).

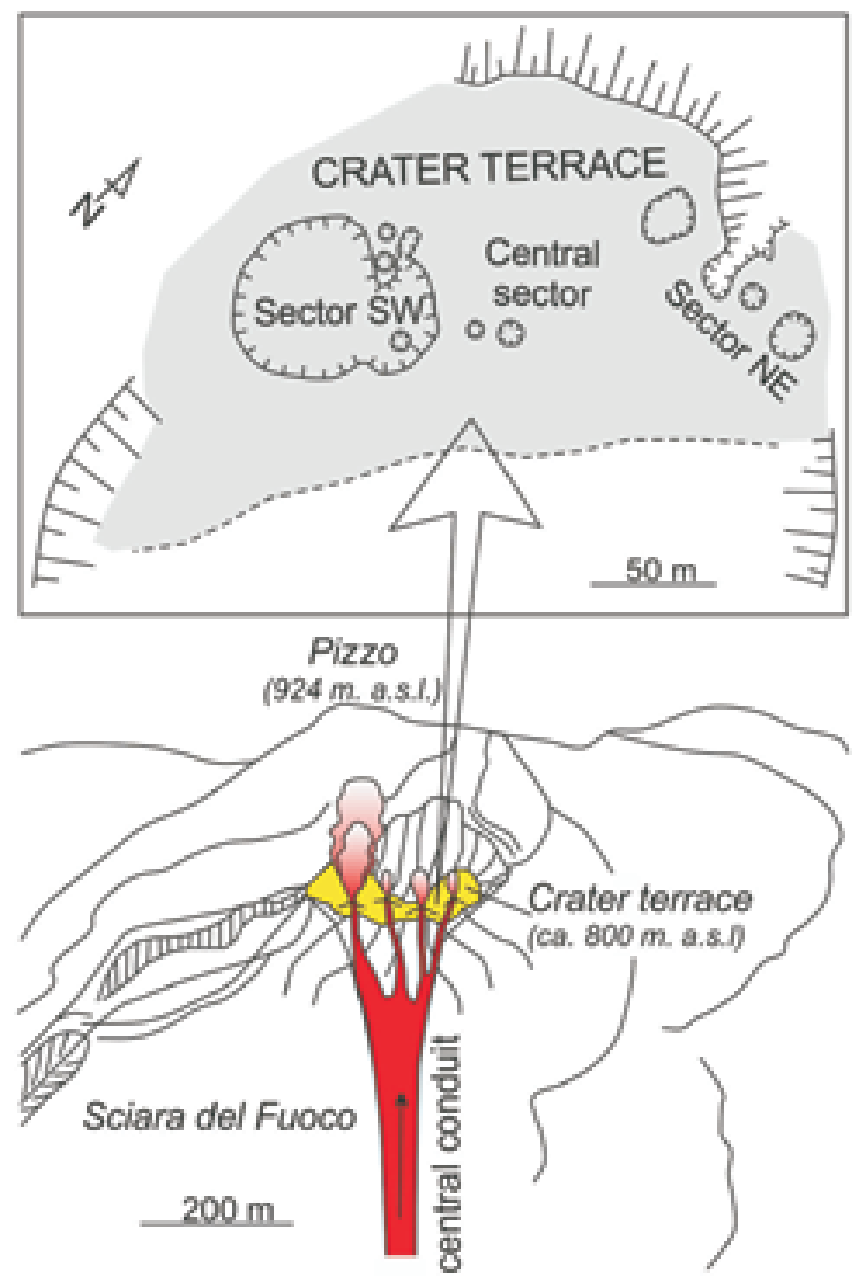

Fig. 17. Sketch map of the Stromboli crater terrace during 2016 (drown based on the Google Maps) and cross section of central conduit near surface - Schematyczny plan tarasu z kraterami w roku 2016 (na podstawie zdjęcia z Google Maps) i przekrój przez górną część komina wulkanicznego

Pyroclast ejection often occurs in short-lived jets, with velocities exceeding $400 \mathrm{~m} / \mathrm{s}$ (Taddeucci et al., 2013), thus being supersonic with respect to the surrounding atmosphere; averages of $50-100 \mathrm{~m} / \mathrm{s}$ are characteristic to bomb velocities. Analyses of surveillance videos of persistent volcanic activity (>4000 explosions during 2005-2009; Taddeucci et al., 2013) show that there is a positive relationship linking explosion frequency and jet height. More frequent and stronger explosions at the surface are caused by increased magma flux at depth. 

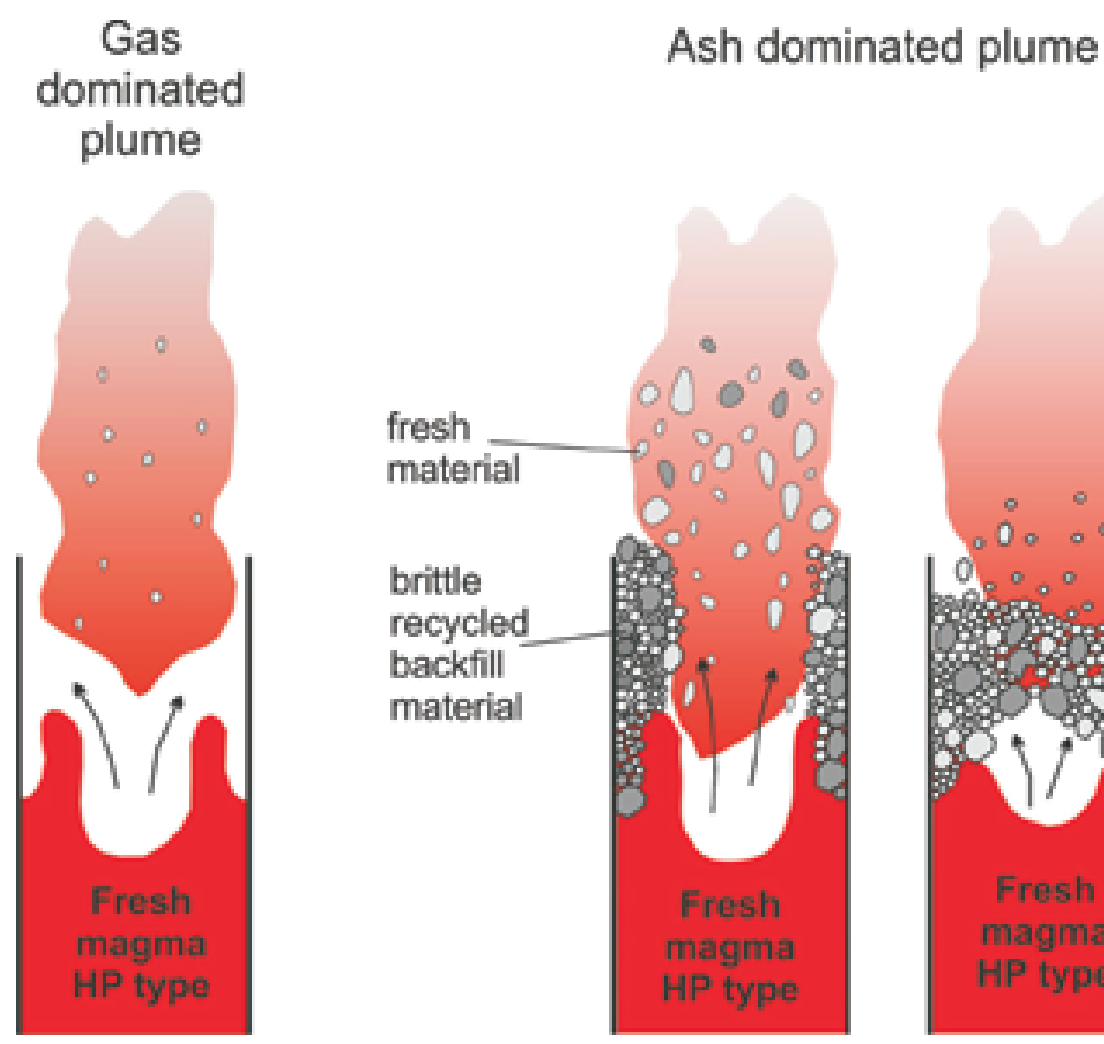

\section{Bomb dominated plume}
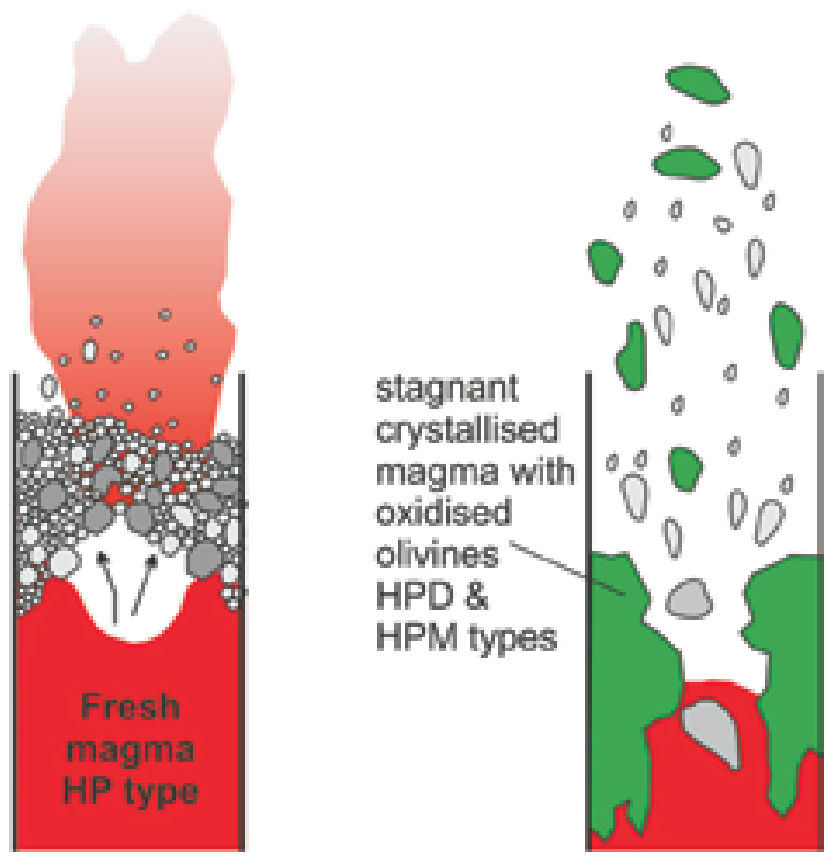

Fig. 18. Conceptual sketch of the different explosion types (redrawn after Leduc et al., 2015) • Schematyczny obraz trzech typów eksplozji (za Leduc et al., 2015) z różnym udziałem gazów (fumaroli) i różnej wielkości materiału piroklastycznego

The persistent $\mathrm{SO}_{2}$ gas flux of $200 \mathrm{t} /$ day (Burton et al., 2007 ) indicates that magma is supplied at a rate of $\sim 0.3 \mathrm{~m}^{3} / \mathrm{s}$ (Harris, Ripepe, 2007; Allard et al., 2008) which is approximately one order of magnitude higher than the long term magma extrusion rate $\left(\sim 0.018 \mathrm{~m}^{3} / \mathrm{s}\right.$; Allard et al., 2008).

It means that the most of the un-erupted magma $(\sim 93 \%)$ is cycled back and stored beneath the volcano (Allard et al., 2008).

\section{Mass-wasting events and tsunami}

The Sciara del Fuoco depression with a steeply $\left(45^{\circ}\right)$ inclined slope consists largely of loose debris (scoriae and blocks) intercalated with thin lava flows (Romagnoli et al., 2009). Large mass-wasting events $\left(10^{7}-10^{9} \mathrm{~m}^{3}\right)$ were noted several times in the past (Di Roberto et al., 2010), causing ground deformation of the slope. During lateral effusive eruptions, they can culminate with the collapse of the Sciara del Fuoco segments (Giordano, Porreca, 2009).

The slides may also produce tsunami waves lasting for several minutes (Tinti et al., 2005). Such example is a landslide event on 30th of December 2002, when 5 min after this event, the first tsunami wave struck the westernmost part of the village of Stromboli, with a maximum run-up of about $10 \mathrm{~m}$ (Tinti et al., 2005). The maximum flooding (100 $\mathrm{m}$ inland) occurred in the north-eastern lowland sector of the island, causing extensive damage to infrastructure. The same tsunami affected other volcanic islands and the coasts of Calabria and Sicily (Maramai et al., 2005a). Tsunami events were reported a few times during the last 70 years; most probably, all of them were triggered by subaqueous landslides within the Sciara del Fuoco (Maramai et al., 2005b).

\section{Walking up volcano}

Climbing the volcano is a mountain excursion, which can be tiring due to the steepness of slopes, their rugged nature and the heat. After large paroxysms and lava effusive events during 2007, the Department of Civil Protection and the Azienda delle Foreste Demaniali della Regione Siciliana have reorganized a network of paths in accordance with the regulations governing works in protected areas. Access to three paths (A, B, C; Fig. 19) leading to the summit area is subject to rules, which may change according to the level of volcanic activity. Once on the island, it is necessary to make enquiries at the Advanced Operational Centre of the Civil Protection (see its location at a map - Fig. 19). The trails were rendered as safe as possible, with a view to unpredictable volcanic phenomena. Each path is supplied with safety signs and information to improve safety. The trails marked in red on the submitted map (Fig. 19) are not recommended by the Department of Civil Protection, because of overgrown vegetation, unstable terrain, and exposition to the potential fall out of heavy volcanic material (for more information see website: www.protezionecivile.it) 
Trail A: from San Vincenzo to the Sciara del Fuoco (Fig. 19).

It leads to an altitude of $400 \mathrm{~m}$; length is $3 \mathrm{~km}$; estimated time needed to pass along the trail is ca. 1.5-3 hours (one way); maximum inclination is $25 \%$; difficulty - easy to average. The trail was designed for leisurely walks along the mountain's pristine areas (Fig. 20).

It is possible to return back down by a cobblestone track close to the Sciara del Fuoco. Interesting sites: a) various relief forms related to lava flows emitted during the Roman times from an effusive vent opened due to a few fractures on the slope's north eastern flank; b) lavas and eruptive material from the Vancori and Neostromboli stages; c) recent pyroclastic material along the crest of the Sciara del Fuoco depression; d) panorama view on the NE part of Stromboli, Strombolicchio, and the village of Stromboli.

Trail B: from San Vincenzo to Pizzo sopra la Fossa (Fig. 19).

It leads to an altitude of $910 \mathrm{~m}$ (Pizzo); length is $3.0 \mathrm{~km}$; estimated time needed to pass along the trail is ca. 2.5 hours (one way); maximum inclination is $35 \%$; difficulty - medium. The path allows for easier access to the top of the mountain from the NE side leading along the Nel Cannestrà ridge. The ascent to the top from this area, traditionally considered as the safest one by Stromboli's inhabitants, is the least exposed to fall out of boulders and volcanic bombs hurled by paroxysmal explosions. Interesting sites: a) along the entire route - a view of both NE Stromboli and Strombolicchio; b) lava flow ridge called 'del Cannestrà' with masses of welded scoriae spatter, erupted from a fissure on the NE slope of the volcano during 10-6 ka; c) large amounts of black sands with large crystals of pyroxene (up to $1 \mathrm{~cm}$ ), formed over the last 1000 years due to the explosive activity and carried by winds blowing from west to east; d) view onto the crater area with active craters and the higher section of the Sciara del Fuoco; e) a gorge (Forgia Vecchia gorge) and the rocky ridges with rich vegetation of the Aeolian Cistus aeolicus, a resin-bearing species.

Trail C: from Ginostra to Portella Ginostra (Fig. 19).

It leads to an altitude of $910 \mathrm{~m}$ (Pizzo); length is $3.5 \mathrm{~km}$; estimated time needed to pass along the trail is ca. 3 hours (one way); maximum inclination is $40 \%$; difficulty - medium-high. The trail leads at an altitude of $800 \mathrm{~m}$, along the western side of the Sciara del Fuoco, proceeding onwards to the Pizzo. From Portella Ginostra it is possible to proceed along the rocky crest going north for $200 \mathrm{~m}$ and observe the eruptive activity of the South West crater. Interesting sites: a) terraced cultivated areas bounded by dry stone walls, where olive trees and prickly pears grow; b) solar panelled power station $(80 \mathrm{~kW}$, built in 2003 providing electricity to the village of Ginostra); c) specific morphology of the lower part of the Sciara del Fuoco created by marine erosion (coast line's retreat); d) rocky vertical cliff-faces arising alongside the slope of the Sciara representing the eroded dykes; e) large field of volcanic bombs between altitudes of 730 and $800 \mathrm{~m}$ a.s.l. deposited during large-scale paroxysms.

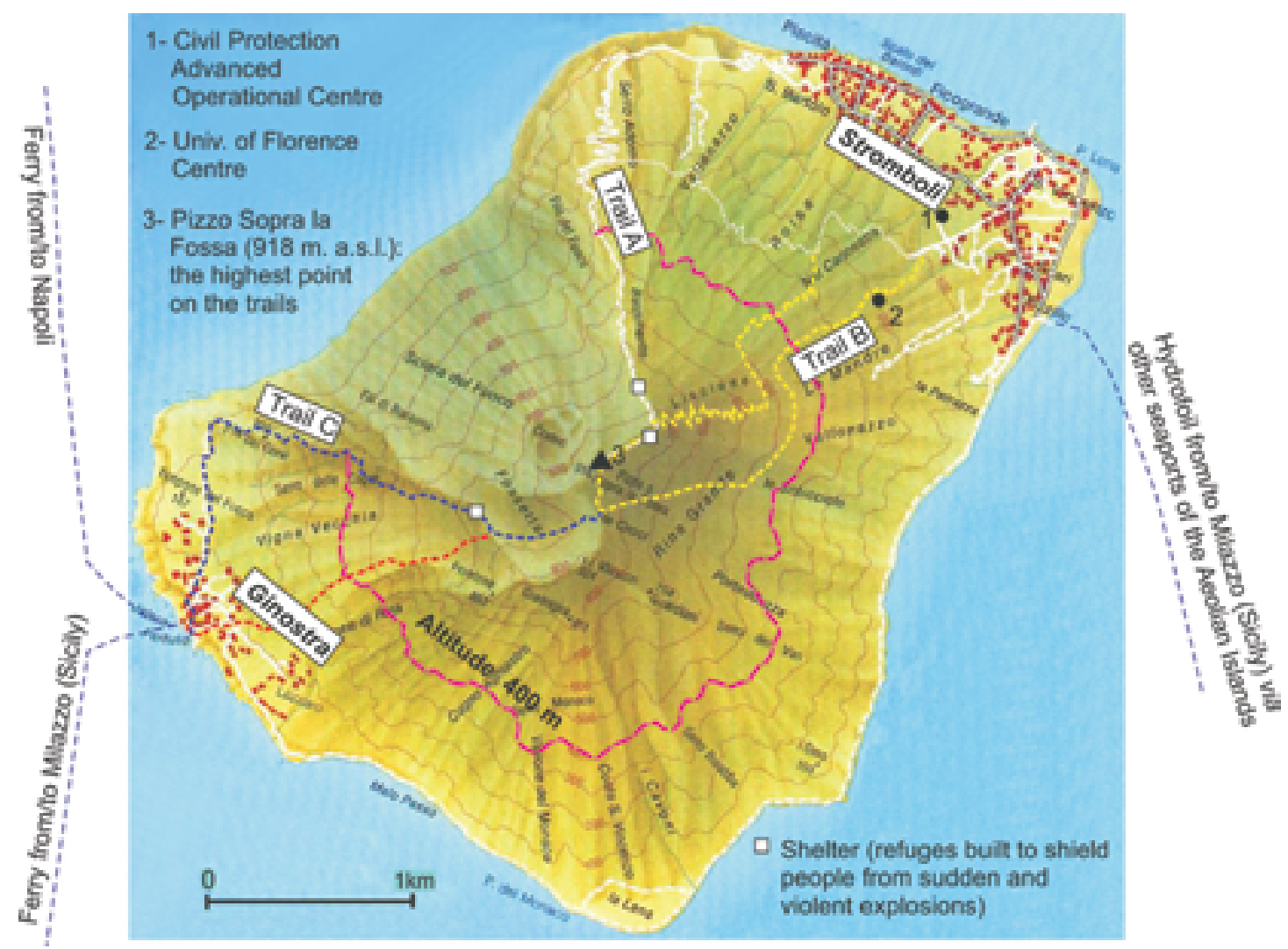

Fig. 19. Topographic map of the Stromboli Volcano (after http://www.mappery.com/map-of/Stromboli-Map) with three trails to the summit (based on http://www.protezionecivile.gov.it/resources/cms/documents/cartasentieri2008_stromboli_eng.pdf) • Mapa topograficzna Stromboli (za http://www.mappery.com/map-of/Stromboli-Map) z trzema ścieżkami turystycznymi prowadzącymi na wierzchołek wulkanu (na podstawie http://www.protezionecivile.gov.it/resources/cms/documents/cartasentieri2008_stromboli_eng.pdf) 


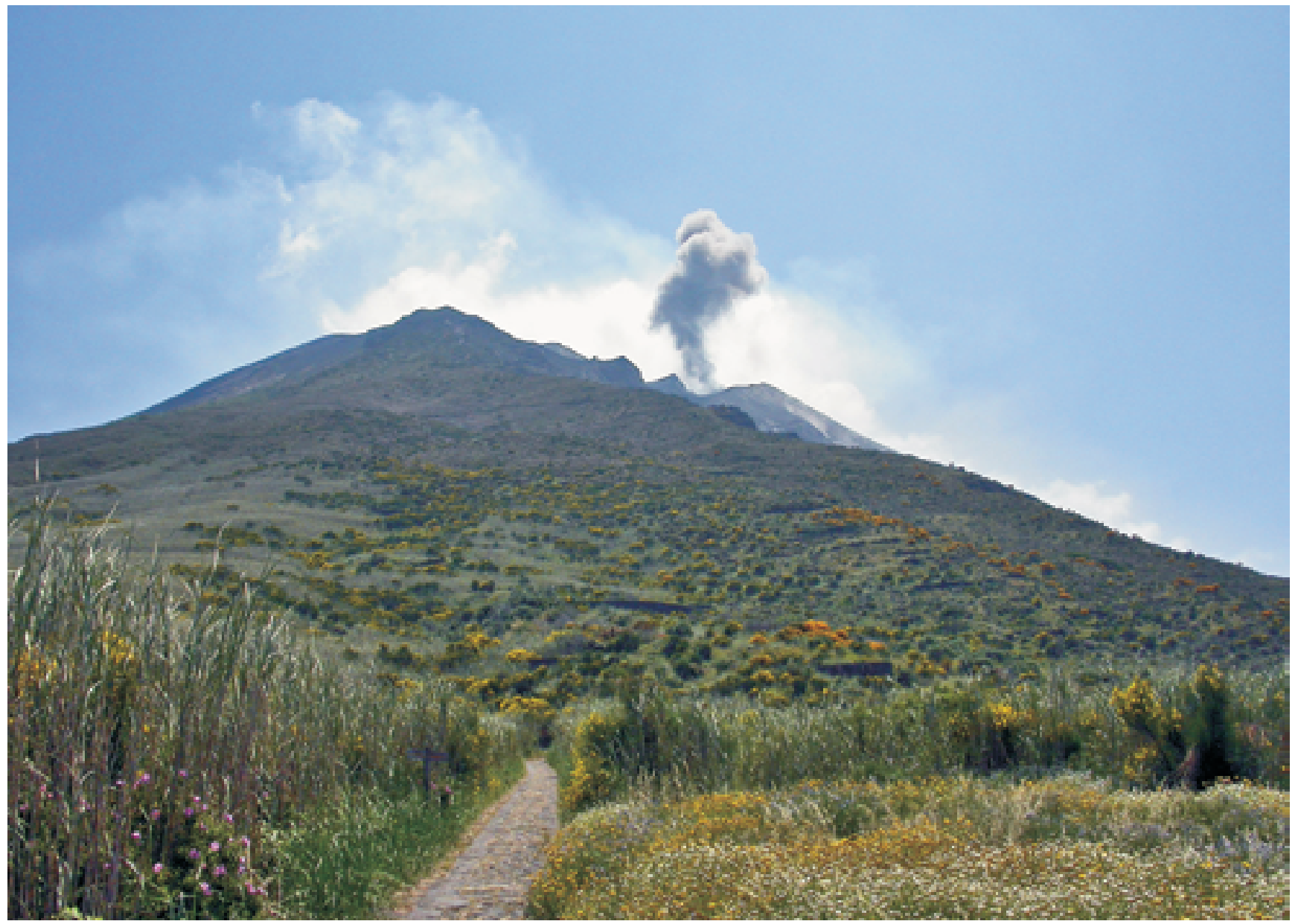

Fig. 20. View on the NE part of Stromboli from trail A, close to crest of Sciara del Fuoco, photo M. Bąk • Widok z NE części wyspy na ścieżkę A prowadzącą wzdłuż krawędzi depresji Sciara del Fuoco, fot. M. Bąk

Climbing above the altitude of $400 \mathrm{~m}$ (see position on Fig. 19) to the top of Stromboli is, by law, severely restricted and only permitted if you join a guided tour. The guide, in conformity with the regulation in force, takes the decision on whether or not an excursion can take place, considering the meteorological conditions and the state of volcanic activity. Before setting out on an excursion (and after return), the guide provides the Stromboli Carabinieri Station with details about the list of tourists, the route, the departure time and estimated time of return.

\section{Closing remarks}

Thousands of tourists from May to October travel to Stromboli to experience the added element of adventure with volcanic features. Nevertheless, everyone who comes to the island should remember that Stromboli Island and Strombolicchio are wildlife reserves under total (more than 50\% of area) and controlled preservation territorial norms. In turn, the visitors sailing around the volcano should be aware that no bathing and navigation is allowed 400 metres from the Sciara del Fuoco coastline.

Protected sites such as Stromboli play an important role in volcanic geotourism, as they can offer knowledge on geological heritage. Recently, the access to this form of knowledge gaining seems to be easy and relatively cheap. The tourists can fly to Napoli or to one of the airports in Sicily, and Catania, take the hydrofoils to the Aeolian Islands, and after a 2-4 hour walk up the volcano, one can hear every 10-20 minutes thunders of its explosions, and observe the clouds of gas, ash and volcanic bombs.

\section{References (Literatura)}

Aiello G., Di Fiore V., Marsella E., Passaro S., 2014. High resolution seismic data coupled to Multibeam bathymetry of Stromboli island collected in the frame of the Stromboli geophysical experiment: implications with the marine geophysics and volcanology of the Aeolian Arc volcanic complex (Sicily, Southern Tyrrhenian Sea, Italy). Springer Plus, 3: 232. [doi: 10.1186/2193-1801-3-232].
Aiuppa A., Bertagnini A., Métrich N., Moretti R., Di Muro A., Liuzzo M., Tamburello G., 2010. A model of degassing for Stromboli volcano. Earth and Planetary Science Letters, 295: 195-204.

Allard P., 2010. A CO(2)-rich gas trigger of explosive paroxysms at Stromboli basaltic volcano, Italy. Journal of Volcanology and Geothermal Research, 189: 363-374. 
Allard P., Carbonnelle J., Metrich N., Loyer H., Zettwoog, P., 1994. Sulfur output and magma degassing budget of Stromboli volcano. Nature, 368: 326-330.

Allard P., Aiuppa A., Burton M., Caltabiano T., Federico C., Salerno G., La Spina A., 2008. Crater gas emissions and the magma feeding system of Stromboli volcano. In: Calvari S., Inguaggiato S., Ripepe M., Rosi M. (eds), The Stromboli Volcano: An integrated study of the 2002-2003 eruption. American Geophysical Union - Geophysics Monograph Series, Washington DC, 182: 65-80 [doi: 10.1029/182gm07].

Barberi F., Rosi M., Sodi A., 1993. Volcanic hazard assessment at Stromboli based on review of historical data. Acta Vulcanologica, 3: 173-187.

Boccaletti M., Nicolich R., Tortorici L., 1984. The Calabrian arc and the Ionian Sea in the evolution of the central Mediterranean. Marine Geology, 55: 219-245.

Burton M., Allard P., Mure F., La Spina A., 2007. Magmatic gas composition reveals the source depth of slug-driven Strombolian explosive activity. Science, 317: 227-230.

Coppola D., Piscopo D., Laiolo M., Cigolini C., Delle Donne D., Ripepe M., 2012. Radiative heat power at Stromboli volcano during 2000-2011: Twelve years of MODIS observations. Journal of Volcanology and Geothermal Research, 215-216: 48-60.

Cortes J.A., Wilson M., Condliffea T.E., Francalanci L., Chertkoff D.G., 2005. The evolution of the magmatic system of Stromboli volcano during the Vancori period (26-13.8 ky). Journal of Volcanology and Geothermal Research, 147: 1-38.

Delle Donne D., Marchetti E., Ripepe M., Ulivieri G., Lacanna G., 2006. Monitoring explosive volcanic activity using thermal images, Stromboli volcano, Italy. Eos, Transactions, American Geophysical Union, Fall Meeting 2006 Abstracts, 79: 1795.

Di Roberto A., Bertagnini A., Pompilio M., Gamberi F., Marani M.P., Rosi A.M., 2008. Newly discovered submarine flank eruption at Stromboli volcano (Aeolian Islands, Italy). Geophysical Research Letters, 35 [doi: 10.1029/2008GL034824].

Di Roberto A., Rosi M., Bertagnini A., Marani M.P., Gamberi F., 2010. Distal turbidites and tsunamigenic landslides of Stromboli Volcano (Aeolian Islands, Italy). In: Mosher D.C., Shipp C., Moscardelli L., Chaytor J., Baxter C., Lee H., Urgeles R. (eds), Submarine mass movements and their consequences. Springer, Berlin Heidelberg, Advances in Natural and Technological Hazard Research, 28: 719-732.

Falsaperla S., Lanzafame G., Longo V., Spampinato S., 1999. Regional stress field in the area of Stromboli (Italy): insights into structural data and crustal tectonic earthquakes. Journal of Volcanology and Geothermal Research, 88: 147-166.

Favalli M., Karatson D., Mazzuoli R., Pareschi M.T., Ventura G., 2005. Volcanic geomorphology and tectonics of the Aeolian Archipelago (southern Italy) based on integrated DEM data. Bulletin of Volcanology, 68: $157-170$.

Francalanci L., Tommasini S., Conticelli S., Davies G.R., 1999. Sr isotope evidence for short magma residence time for the 20th century activity at Stromboli volcano, Italy. Earth and Planetary Science Letters, 167, 1-2: 61-69.

Francalanci L., Davies G.R., Lustenhouwer W., Tommasini S., Mason P.R.D., Conticelli S., 2005. Intra-grain Sr isotope evidence for crystal recycling and multiple magma reservoirs in the recent activity of Stromboli volcano, southern Italy. Journal of Petrology, 46: 1997-2021.

Francalanci L., Lucchi F., Keller J., De Astis G., Tranne C.A., 2013. Eruptive, volcano-tectonic and magmatic history of the Stromboli volcano (north-eastern Aeolian archipelago). Geological Society, London, Memoirs, 37: 397-471.

Gabbianelli G., Gillot P.Y., Lanzafame G., Romagnoli C., Rossi P.L., 1990. Tectonic and volcanic evolution of Panarea (Aeolian Islands, Italy). Marine Geology, 92: 313-326.

Gillot P.Y., Keller J., 1993. Age dating of Stromboli. Acta Vulcanologica, 3: 69-77.

Giordano G., Porreca M., 2009. Field observations on the initial lava flow and the fracture system developed during the early days of the Stromboli 2007 eruption. Journal of Volcanology and Geothermal Research, 182: 145-154.

Guest J., Cole P., Duncan A., Chester D., 2003. Volcanoes of Southern Italy. The Geological Society, Bath, UK

Gurioli L., Colo L., Bollasina A.J., Harris A.J.L., Whittington A., Ripepe M., 2014. Dynamics of strombolian explosions: inferences from inferences from field and laboratory studies of erupted bombs from Stromboli volcano. Journal of Geophysical Research, 119: 319-345.

Harris A., Ripepe M., 2007. Temperature and dynamics of degassing at Stromboli. Journal of Geophysical Research-Solid Earth, 112 [doi:10.1029/2006JB004393].
Harris A.J.L., Delle Donne D., Dehn J., Ripepe M., Worden K., 2013. Volcanic plume and bomb field masses from thermal infrared camera imagery. Earth and Planetary Science Letters, 365: 77-85.

Hornig-Kjarsgaard I., Keller J., Koberski U., Stadlbauer E., Francalanci L., Lenhart R., 1993. Geology, stratigraphy, and volcanological evolution of the island of Stromboli, Aeolian Arc, Italy. Acta Vulcanologica, 3: 21-68.

Jaupart C., Vergniolle S., 1989. The generation and collapse of foam layer at the roof of a basaltic magma chamber. Journal of Fluid Mechanics, 203: $347-380$.

Keller J., Hornig-Kjarsgaard I., Koberski U., Stadlbauer E., Lenhart R., 1993. Geological map of the island of Stromboli - scale $1: 10,000$. Acta Vulcanologica, 3, Pisa, Italy, Appendix.

Leduc L., Gurioli L., Harris A., Colò L., Rose-Koga E.F., 2015. Types and mechanisms of strombolian explosions: characterization of a gas-dominated explosion at Stromboli. Bulletin of Volcanology, 77: 8 [doi:10.1007/ s00445-014-0888-5].

Mantovani E., Albarello D., Babbucci D., Tamburelli C., 1997. Recent/present tectonic processes in the Italian region and their relation with seismic and volcanic activity. Annales Tectonicae, 11(1-2): 27-57.

Maramai A., Graziani L., Alessio G., Burrato P., Colini L., Cucci L., Nappi R., Nardi A., Vilardo G., 2005a. Near- and far-field survey report of the 30 December 2002 Stromboli (Southern Italy) tsunami. Marine Geology, 215: 93-106.

Maramai A., Graziani L., Tinti S., 2005b. Tsunamis in the Aeolian Islands (Southern Italy): a review. Marine Geology, 215: 11-21.

Marani M., Trua T., 2002. Thermal constriction and slab tearing at the origin of a superinflated spreading ridge: Marsili volcano (Tyrrhenian Sea). Journal of Geophysical Research, 107: 2188-2203.

Marsella M., Baldi P., Coltelli M., Fabris M., 2012. The morphological evolution of the Sciara del Fuoco since 1868: reconstructing the effusive activity at Stromboli volcano. Bulletin of Volcanology, 74: 231-248.

Martelli M., Rizzo A.L., Renzulli A., Ridolfi F., Arienzo I., Rosciglione A., 2014. Noble-gas signature of magmas from a heterogeneous mantle wedge: The case of Stromboli volcano (Aeolian Islands, Italy). Chemical Geology, 368: 39-53.

Mercalli G., 1881. Natura nelle eruzioni dello Stromboli ed in generale dell'attivita sismico-vulcanica delle Isole Eolie. Atti Societa Italiana Scienze Naturali, 24: 105-134.

Mercalli G., 1883. Vulcani e Fenomeni Vulcanici. In: Negri G., Stoppani A., Mercalli G. (eds), Geologia d'Italia, 3: 217-218.

Metrich N., Bertagnini A., Di Muro A., 2010. Conditions of magma storage, degassing and ascent at Stromboli: new insights into the volcano plumbing system with inferences on the eruptive dynamics. Journal of Petrology, 51: 603-626.

Milano G., Vilardo G., Luongo G., 1994. Continental collision and basin opening in Southern Italy: a new plate subduction in the Tyrrhenian Sea? Tectonophysics, 230: 249-264.

Neri M., Lanzafame G., 2009. Structural features of the 2007 Stromboli eruption. Journal of Volcanology and Geothermal Research, 182: 137-144.

Patrick M.R., Harris A.J.L., Ripepe M., Dehn J., Rothery D., Calvari S., 2007. Strombolian explosive styles and source conditions: insights from thermal (FLIR) video. Bulletin of Volcanology, 69: 769-784.

Parfitt E.A., 2004. A discussion of the mechanisms of explosive basaltic eruptions. Journal of Volcanology and Geothermal Research, 134: 77-107.

Parfitt E.A., Wilson L., 1995. Explosive volcanic eruptions - IX. The transition between Hawaiian-style lava fountaining and Strombolian explosive activity. Geophysical Journal International, 121: 226-232.

Patrick M.R., Harris A.J.L., Ripepe M., Dehn J., Rothery D.A., Calvari S., 2007. Strombolian explosive styles and source conditions: insights from thermal (FLIR) video. Bulletin of Volcanology, 69: 769-784.

Peccerillo A., Panza G., 1999. Upper mantle domains beneath central-southern Italy: petrological, geochemical and geophysical constraints. Pure and Applied Geophysics, 156: 421-443.

Petrone C.M., Braschi E., Francalanci L., 2009. Understanding the collapseeruption link at Stromboli, Italy: A microanalytical study. Journal of Volcanology and Geothermal Research, 188: 315-332.

Pichavant M., Pompilio M., D’Oriano C., Carlo I.D., 2011. Petrography, mineralogy and geochemistry of a primitive pumice from Stromboli: implications for the deep feeding system. European Journal of Mineralogy, 23: 499-517.

Pistolesi M., Delle Donne D., Pioli L., Rosi M., Ripepe M., 2011. The 15 March 2007 explosive crisis at Stromboli volcano, Italy: assessing physical parameters through a multidisciplinary approach. Journal of Geophysical Research-Solid Earth, 116 [doi: 10.1029/2011JB008527]. 
Pompilio M., Bertagnini A., Metrich N., 2012. Geochemical heterogeneities and dynamics of magmas within the plumbing system of a persistently active volcano: evidence from Stromboli. Bulletin of Volcanology, 74: 881-894.

Ripepe M., Harris A.J.L., Carniel R., 2002. Thermal, seismic and infrasonic evidences of variable degassing rates at Stromboli volcano. Journal of Volcanology and Geothermal Research, 118: 285-297.

Romagnoli C., Kokelaar P., Casalbore D., Chiocci F.L., 2009. Lateral collapses and active sedimentary processes on the northwestern flank of Stromboli volcano, Italy. Marine Geology, 265: 101-119.

Rosi M., Bertagnini A., Landi P., 2000. Onset of the persistent activity at Stromboli volcano (Italy). Bulletin of Volcanology, 62: 294-300.

Rosi M., Bertagnini A., Harris A.J.L., Pioli L., Pistolesi M., Ripepe M., 2006. A case history of paroxysmal explosion at Stromboli: timing and dynamics of the April 5, 2003 event. Earth and Planetary Science Letters, 243: 594-606.

Rosi M., Pistolesi M., Bertagnini A., Landi P., Pompilio M., Di Roberto A., 2013. Stromboli volcano, Aeolian Islands (Italy): present eruptive activity and hazards. Geological Society, London, Memoirs, 37: 473-490.

Ripepe M., Rossi M., Saccorotti G., 1993. Image-processing of explosive activity at Stromboli. Journal of Volcanology and Geothermal Research, 54: 335-351.

Rizzo A.L. Federico C., Inguaggiato S., Sollami A., Tantillo M., Vita F., Bellomo S., Longo M., Grassa F., Liuzzo M., 2015. The 2014 effusive eruption at Stromboli volcano (Italy): Inferences from soil $\mathrm{CO}_{2}$ flux and ${ }^{3} \mathrm{He} /{ }^{4} \mathrm{He}$ ratio in thermal waters. Geophysical Research Letter [doi: 10.1002/2014GL062955].
Taddeucci J., Palladino D.M., Sottili G., Bernini D., Andronico D., Cristaldi A., 2013. Linked frequency and intensity of persistent volcanic activity at Stromboli (Italy). Geophysical Research Letters, 40 [doi: 10.1002/grl.50652]

Taddeucci J., Edmonds M., Houghton B., James M.R., Vergniolle S., 2015. Hawaiian and Strombolian Eruptions. In: Sigurdsson H., Houghton B., McNutt S., Rymer S., Stix J. (eds), The Encyclopedia of Volcanoes, Part 4. Elsevier Inc., chapter 27: 485-502.

Tibaldi A., 2001. Multiple sector collapses at Stromboli volcano, Italy: How they work. Bulletin of Volcanology, 63: 112-125.

Tibaldi A., Corazzato C., Apuani T., Cancelli A., 2003. Deformation at Stromboli volcano (Italy) revealed by rock mechanics and structural geology. Tectonophysics, 361: 187-204.

Tinti S., Manucci A., Pagnoni G., Armigliato A., Zaniboni F., 2005. The 30 December 2002 landslide-induced tsunamis in Stromboli: sequence of the events reconstructed from the eyewitness accounts. Natural Hazards and Earth System Sciences, 5: 763-775.

Tommassini S., Heumann A., Avanzinelli R., Francalanci L., 2007. The Fate of High-Angle Dipping Slabs in the Subduction Factory: an Integrated Trace Element and Radiogenic Isotope (U, Th, Sr, Nd, Pb) Study of Stromboli Volcano, Aeolian Arc, Italy. Journal of Petrology 48: 2407 2430.

Vergniolle S., Jaupart C., 1986. Separated two-phase flow and basaltic eruptions. Journal of Geophysical Research, 91: 12842-12860.

Vezzoli L., Corazzato C., 2016. Volcaniclastic dykes tell on fracturing, explosive eruption and lateral collapse at Stromboli volcano (Italy). Journal of Volcanology and Geothermal Research, 318: 55-72. 